\title{
Significant contrasts in aerosol acidity between China and the United States
}

\author{
Bingqing Zhang ${ }^{1}$, Huizhong Shen ${ }^{1,2}$, Pengfei Liu ${ }^{3}$, Hongyu Guo ${ }^{4,5}$, Yongtao Hu${ }^{1}$, Yilin Chen ${ }^{1,2}$, Shaodong Xie ${ }^{6}$, \\ Ziyan $\mathrm{Xi}^{6}$, T. Nash Skipper ${ }^{1}$, and Armistead G. Russell ${ }^{1}$ \\ ${ }^{1}$ School of Civil and Environmental Engineering, Georgia Institute of Technology, Atlanta, Georgia 30332, USA \\ ${ }^{2}$ School of Environmental Science and Engineering, Southern University of Science and Technology, \\ Shenzhen, Guangdong, 518055, China \\ ${ }^{3}$ School of Earth and Atmospheric Sciences, Georgia Institute of Technology, Atlanta, Georgia 30332, USA \\ ${ }^{4}$ Department of Chemistry, University of Colorado, \\ Boulder, Colorado 80309, USA \\ ${ }^{5}$ Cooperative Institute for Research in Environmental Sciences, University of Colorado, \\ Boulder, Colorado 80309, USA \\ ${ }^{6}$ College of Environmental Sciences and Engineering, State Key Joint Laboratory of Environmental Simulation and Pollution \\ Control, Peking University, Beijing, 100871, China
}

Correspondence: Huizhong Shen (shenhz@ sustech.edu.cn)

Received: 20 August 2020 - Discussion started: 10 September 2020

Revised: 20 April 2021 - Accepted: 20 April 2021 - Published: 1 June 2021

\begin{abstract}
Aerosol acidity governs several key processes in aerosol physics and chemistry, thus affecting aerosol mass and composition and ultimately climate and human health. Previous studies have reported aerosol $\mathrm{pH}$ values separately in China and the United States (USA), implying different aerosol acidity between these two countries. However, there is debate about whether mass concentration or chemical composition is the more important driver of differences in aerosol acidity. A full picture of the $\mathrm{pH}$ difference and the underlying mechanisms responsible is hindered by the scarcity of simultaneous measurements of particle composition and gaseous species, especially in China. Here we conduct a comprehensive assessment of aerosol acidity in China and the USA using extended ground-level measurements and regional chemical transport model simulations. We show that aerosols in China are significantly less acidic than in the USA, with $\mathrm{pH}$ values 1-2 units higher. Based on a proposed multivariable Taylor series method and a series of sensitivity tests, we identify major factors leading to the $\mathrm{pH}$ difference. Compared to the USA, China has much higher aerosol mass concentrations (gas + particle, by a factor of 8.4 on average) and a higher fraction of total ammonia (gas + particle) in the aerosol composition. Our assessment shows that the differ-
\end{abstract}

ences in mass concentrations and chemical composition play equally important roles in driving the aerosol $\mathrm{pH}$ difference between China and the USA - increasing the aerosol mass concentrations (by a factor of 8.4) but keeping the relative component contributions the same in the USA as the level in China increases the aerosol $\mathrm{pH}$ by $\sim 1.0$ units and further shifting the chemical composition from US conditions to China's that are richer in ammonia increases the aerosol $\mathrm{pH}$ by $\sim 0.9$ units. Therefore, China being both more polluted than the USA and richer in ammonia explains the aerosol $\mathrm{pH}$ difference. The difference in aerosol acidity highlighted in the present study implies potential differences in formation mechanisms, physicochemical properties, and toxicity of aerosol particles in these two countries.

\section{Introduction}

As an intrinsic aerosol property, aerosol acidity (usually characterized by aerosol $\mathrm{pH}$ ) plays an important role in a variety of aerosol physical and chemical processes (Pye et al., 2020). Aerosol acidity can modulate aerosol mass by controlling the gas-particle partitioning of volatile and semi-volatile acids 
(such as $\mathrm{HCl}-\mathrm{Cl}^{-}$and $\mathrm{HNO}_{3}-\mathrm{NO}_{3}^{-}$) (Guo et al., 2016) and can influence production rates of secondary aerosols through heterogeneous pathways (Jang et al., 2002; Surratt et al., 2010; Pathak et al., 2011). Acidity also affects aerosol optical properties via proton dissociation of organic functional groups (Mo et al., 2017) and the morphology or phase state of organic aerosols (Losey et al., 2016, 2018). Recent evidence links aerosol acidity to aerosol toxicity and health outcomes. For example, highly acidic aerosols cause greater dissolution of metals which can generate reactive oxygen species in vivo (Fang et al., 2017). High aerosol acidity is associated with increased risks of respiratory disease and cancer (Kleinman et al., 1989; Gwynn et al., 2000; Behera et al., 2015).

Due to the difficulties in directly measuring aerosol $\mathrm{pH}$ (Jang et al., 2002; Li and Jang, 2012), thermodynamic models, including ISORROPIA II (Fountoukis and Nenes, 2007), E-AIM (Clegg et al., 1998), and SCAPE2 (Kim and Seinfeld, 1995), have been widely used to calculate aerosol $\mathrm{pH}$ based on measured gaseous and particle composition and meteorological data such as relative humidity (RH) and temperature. Multiple studies suggest that these models can reproduce the partitioning of semi-volatile species including $\mathrm{HNO}_{3}-\mathrm{NO}_{3}^{-}$ and $\mathrm{NH}_{4}^{+}-\mathrm{NH}_{3}$, which are sensitive to aerosol $\mathrm{pH}$ (Guo et al., 2015, 2016; Hennigan et al., 2015).

Analyses of field observations in different regions of the United States (USA) have indicated that aerosol acidity is typically high. For example, Weber et al. (2016) showed that aerosol $\mathrm{pH}$ in the southeastern USA was buffered to be consistently in the range of 0-2 despite a substantial sulfate reduction over the past 15 years, and the same trend may be applicable to other regions. Studies in the northeastern USA and California also found highly acidic aerosols with mean pH values of 0.8 and 1.9, respectively (Guo et al., 2017a). Aerosol pH in the midwestern USA was typically higher than in other areas, with an average of 3.8 (Lawal et al., 2018). Studies in China, on the other hand, have found generally higher aerosol $\mathrm{pH}$. Several studies in the heavily polluted North China Plain (NCP) region reported average $\mathrm{pH}$ of 3.5-5.2 (Shi et al., 2017, 2019; Ding et al., 2019; Song et al., 2019; Wang et al., 2020). Xi' an, a city in northwest China, had aerosol $\mathrm{pH}$ values of up to 5 (Wang et al., 2016; Guo et al., 2017b). Some sites in southeast China had lower aerosol $\mathrm{pH}$, such as the site in Guangzhou which had an average of 2.3 (Jia et al., 2020). A comprehensive, nationwide comparison of aerosol $\mathrm{pH}$ between China and the USA can provide a better understanding of the factors driving aerosol $\mathrm{pH}$ and its effect on aerosol formation mechanisms and properties (Pathak et al., 2009; Guo et al., 2017a; Wang et al., 2020). However, such comparisons are still scarce (Guo et al., 2017b; Nenes et al., 2020; Zheng et al., 2020), primarily because of a lack of extensive simultaneous measurements of aerosol composition and semi-volatile gaseous compounds in China.

In this study, we compared the aerosol mass concentrations, chemical composition, and acidity between China and the USA based on 1-year measurements from 34 ground monitoring sites in the USA and 16 sites in China (mostly clustered in the NCP). In order to extend the spatial coverage to nationwide scales, we employed the Community Multiscale Air Quality (CMAQ) model to simulate the concentrations of gaseous and particle species which were used to calculate aerosol $\mathrm{pH}$ across both countries. We propose a new method to identify the factors driving the $\mathrm{pH}$ difference between these two countries and discuss the causes and implications of the $\mathrm{pH}$ difference.

\section{Data collection and method}

\subsection{Observational data}

Measurements of gaseous species (including $\mathrm{HNO}_{3}, \mathrm{NH}_{3}$, and $\mathrm{HCl}$ ) and particle components (including $\mathrm{SO}_{4}^{2-}, \mathrm{NO}_{3}^{-}$, $\mathrm{NH}_{4}^{+}, \mathrm{Cl}^{-}$, and nonvolatile cations (NVCs)) from monitoring networks in China and the USA are used for analysis and comparison in this study. NVCs considered are $\mathrm{Na}^{+}, \mathrm{Mg}^{2+}$, $\mathrm{K}^{+}$, and $\mathrm{Ca}^{2+}$. The names and locations of the monitoring sites can be found in Tables S1 and S2. The sum of total observed aerosol ionic compounds is defined as water-soluble ions (WSIs), though it is recognized that not all of the ions are routinely measured (e.g., trace species and organic ions). We also study the partitioning of semi-volatile species including $\mathrm{NH}_{3}-\mathrm{NH}_{4}^{+}$and $\mathrm{HNO}_{3}-\mathrm{NO}_{3}^{-}$because they are sensitive to $\mathrm{pH}$, especially when the partitioning ratios, $\varepsilon\left(\mathrm{NH}_{4}^{+}\right)$ and $\varepsilon\left(\mathrm{NO}_{3}^{-}\right)$, defined as the molar ratio of $\mathrm{NH}_{4}^{+}$to total ammonia $\left(\mathrm{TNH}_{3}=\mathrm{NH}_{3}+\mathrm{NH}_{4}^{+}\right.$) and the molar ratio of $\mathrm{NO}_{3}^{-}$to total nitrate $\left(\mathrm{TNO}_{3}=\mathrm{HNO}_{3}+\mathrm{NO}_{3}^{-}\right.$), are around $50 \%$ (Guo et al., 2017a; Chen et al., 2019).

In the USA, observational data are from co-located Clean Air Status and Trends Network (CASTNET) (https://www. epa.gov/castnet, last access: 23 January 2021) and Ammonia Monitoring Network (AMoN) (http://nadp.slh.wisc.edu/ amon/, last access: 23 January 2021) sites. CASTNET and AMoN sites are assumed to be co-located if they are within $1 \mathrm{~km}$ of one another. Observations from co-located sites are then combined for $\mathrm{pH}$ calculation. Weekly ambient concentrations of gases and particulate species, including $\mathrm{HNO}_{3}$, $\mathrm{SO}_{4}^{2-}, \mathrm{NO}_{3}^{-}, \mathrm{NH}_{4}^{+}, \mathrm{Cl}^{-}$, and $\mathrm{NVCs}$, are available from CASTNET sites, while biweekly concentrations of $\mathrm{NH}_{3}$ are available from AMoN sites. To match biweekly data of $\mathrm{NH}_{3}$ from AMoN to weekly data of other species from CASTNET, the same $\mathrm{NH}_{3}$ data are used for both weeks of the CASTNET samples. This assumption is expected to have a minor effect on $\mathrm{pH}$ estimates, as a previous study found that a 10-times increase in $\mathrm{NH}_{3}$ is required to increase $\mathrm{pH}$ by 1 unit (Guo et al., 2017b). This assumption is also supported in later discussion (Sect. S1). $\mathrm{HCl}$ data are not available, so we use particle-phase $\mathrm{Cl}^{-}$as total $\mathrm{Cl}$ for $\mathrm{pH}$ calculations. Sensitivity tests assuming $\mathrm{HCl}$ concentrations of 4 times the $\mathrm{Cl}^{-}$concentrations or using $\mathrm{HCl}$ concentrations 
derived from $\mathrm{CMAQ}$-modeled $\mathrm{HCl} / \mathrm{Cl}^{-}$ratios show little difference in aerosol $\mathrm{pH}$ compared to the $\mathrm{pH}$ estimated by using particle-phase $\mathrm{Cl}^{-}$as total $\mathrm{Cl}$ (Fig. S1). Considering the small reported change in aerosol $\mathrm{pH}$ in the USA over a long-term period (Weber et al., 2016; Lawal et al., 2018) and the configuration of the chemical transport model which is set up for the year 2011 (see the following section), we use observational data in 2011 to investigate the aerosol $\mathrm{pH}$ in the USA. Only sites with measurements available for all species were selected for this study. There are 34 co-located CASTNET and AMoN sites, which are scattered across the contiguous USA (Figs. 3, S2a). The accuracy of CASTNET measurements has been assessed through the analysis of reference and continuing calibration verification samples with a criterion of $95 \%-105 \%$ (except $\mathrm{NH}_{4}^{+}$, whose accuracy criterion is $90 \%-110 \%$ ). Detailed information about data quality is available in the 2011 annual CASTNET Quality Assurance Report (United States Environmental Protection Agency, 2012a). A previous study demonstrated that the $\mathrm{NH}_{3}$ concentrations measured by the passive AMoN samplers are comparable to annular denuder systems (as a reference system) with a mean relative percent difference of $-9 \%$ (Puchalski et al., 2015).

In China, hourly observational data are extracted from the data-sharing platform operated by the Comprehensive Observation Network for Air Pollution in Beijing-TianjinHebei and Its Surrounding Areas (http://123.127.175.60: 8765/siteui/index, last access: 18 November 2019). This collaborative observation network is supported by multiple institutions and provides simultaneous observations of gaseous and particle species at individual monitoring sites (Wang et al., 2019). We derive daily average concentrations of gaseous species including $\mathrm{NH}_{3}, \mathrm{HNO}_{3}$, and $\mathrm{HCl}$ and of particle species including $\mathrm{NH}_{4}^{+}, \mathrm{NO}_{3}^{-}, \mathrm{Cl}^{-}$, and $\mathrm{NVCs}$ from hourly observational data at 16 monitoring sites for use in $\mathrm{pH}$ calculation. These monitoring sites are clustered in the NCP in eastern China (Fig. S2c). Due to the lack of data quality information, we first process the data by removing unreasonable data points. We define a set of valid data containing all the measured components in $1 \mathrm{~d}$ as one case. We first remove cases with one or more missing components. In this step, 2704 of 5840 cases are removed. We then identify data points that are more than 3 median absolute deviations from the median as outliers and remove cases with any component identified as an outlier. Eventually, 1766 cases remain for subsequent analyses. Although we remove many cases in this process, the remaining cases cover most of the days in a year and are evenly distributed by month (Table S3).

It should be noted that the weekly (or longer) duration of the CASTNET samples in the USA may lead to biases in the measured concentrations especially for volatile species such as ammonium nitrate. Sickles et al. (1999) conducted a comprehensive comparison of measurements using the CASTNET weekly-duration sampling approach with those using a $24 \mathrm{~h}$ duration sampling approach. Both approaches used filter packs. They found that compared to $24 \mathrm{~h}$ sampling, weekly sampling led to low biases of $-5 \%,-5 \%$, and $-0.7 \%$, on average, in measured $\mathrm{HNO}_{3}, \mathrm{NO}_{3}^{-}$, and $\mathrm{NH}_{4}^{+}$, respectively, and high biases of $4 \%$ and $16 \%$, on average, in $\mathrm{SO}_{4}^{2-}$ and $\mathrm{SO}_{2}$, respectively. To evaluate the potential biases in the calculated aerosol $\mathrm{pH}$ due to the weekly-duration sampling, we conduct a sensitivity test to adjust the CASTNET-measured concentrations based on the reported average differences between weekly-duration and $24 \mathrm{~h}$ duration samples (Sickles et al., 1999) (Sect. 3).

\subsection{Model configuration}

We use CMAQ version 5.0.2 (United States Environmental Protection Agency, 2014) to simulate gaseous and particle species concentrations and aerosol $\mathrm{pH}$ in China and the USA. The model domains cover mainland China and the contiguous USA with $124 \times 184$ and $112 \times 148$ horizontal grid cells, respectively. Both are resolved at the $36 \mathrm{~km}$ horizontal resolution with 13 vertical layers extending to $\sim 16 \mathrm{~km}$ above the ground. In both simulations, gas-phase chemistry is modeled with the CB05 chemical mechanism (Yarwood et al., 2005), and the aerosol thermodynamic equilibrium is modeled with ISORROPIA II (Fountoukis and Nenes, 2007).

The meteorological and emission inputs used to drive the China simulation are adopted from "AiMa", an online operational air quality forecasting system (Lyu et al., 2017; AiMa Forecast, 2017). In the AiMa modeling system, the meteorological data are generated with the Weather Research and Forecasting (WRF) model (Skamarock et al., 2008) driven by the $0.5^{\circ}$ global weather forecast products produced by the National Centers for Environmental Prediction (NCEP) Global Forecast System (GFS) model. The AiMa emission inventory was compiled and derived by integrating a variety of inventories and utilizing various activity data and has been continuously updated since its establishment (Lyu et al., 2017). The base year of the current AiMa emission inventory is 2017. For the US simulation, we use WRF-modeled meteorological fields downscaled from the North American Regional Reanalysis (NARR) data (Mesinger et al., 2006) as the meteorological input and the 2011 National Emissions Inventory provided by the US Environmental Protection Agency as the emission input (United States Environmental Protection Agency, 2012b). The base year of the meteorology and emissions is consistent with the year of the measurements in each country (i.e., 2017 for China and 2011 for the USA).

In order to evaluate the model performance against observations, we calculate normalized mean bias (NMB) and normalized root-mean-square error (NRMSE) to evaluate the spatial variation in $\mathrm{pH}$, species concentrations, and partitioning ratios with the following equations: 
$\mathrm{NMB}=\frac{\sum_{1}^{N}\left(C_{\mathrm{m}}-C_{\mathrm{o}}\right)}{\sum_{1}^{N} C_{\mathrm{o}}}$,

NRMSE $=\frac{\sqrt{\frac{\sum_{1}^{N}\left(C_{\mathrm{m}}-C_{\mathrm{o}}\right)^{2}}{N}}}{\bar{C}_{\mathrm{o}}}$,

where $C_{\mathrm{m}}$ is the modeled value, $C_{\mathrm{o}}$ is the observed value, and $N$ is the number of simulation-observation pairs.

\subsection{Aerosol pH calculation}

In this study, we use the ISORROPIA II thermodynamic model (Fountoukis and Nenes, 2007) to determine the composition in a $\mathrm{K}^{+}-\mathrm{Ca}^{2+}-\mathrm{Mg}^{2+}-\mathrm{NH}_{4}^{+}-\mathrm{Na}^{+}-\mathrm{SO}_{4}^{2-}-\mathrm{NO}_{3}^{-}-$ $\mathrm{Cl}^{-}-\mathrm{H}_{2} \mathrm{O}$ aerosol system under equilibrium conditions with gas-phase precursors. Aerosol $\mathrm{pH}$ is calculated based on $\mathrm{H}_{\text {air }}^{+}$ and liquid water content (LWC) from ISORROPIA II output:

$\mathrm{pH}=-\log _{10}\left(\gamma_{\mathrm{H}^{+}} \cdot \mathrm{H}_{\mathrm{aq}}^{+}\right)=-\log _{10}\left(\frac{1000 \gamma_{\mathrm{H}^{+}} \cdot \mathrm{H}_{\mathrm{air}}^{+}}{\mathrm{LWC}}\right)$,

where $\gamma_{\mathrm{H}^{+}}$is the activity coefficient of the hydronium ion which is assumed to be 1 in this study (the binary activity coefficients of ionic pairs, including $\mathrm{H}^{+}$, are calculated in ISORROPIA II), $\mathrm{H}_{\mathrm{aq}}^{+}\left(\mathrm{mol} \mathrm{L}^{-1}\right)$ is the hydronium ion concentration in aerosol liquid water, and $\mathrm{H}_{\text {air }}^{+}\left(\mu \mathrm{g} \mathrm{m}^{-3}\right)$ is the equilibrium particle hydronium ion concentration per volume air. LWC $\left(\mu \mathrm{g} \mathrm{m}^{-3}\right)$ in this study only considers the water uptake by inorganic species. The effect of water uptake by organic species on aerosol $\mathrm{pH}$ has been found to be minor (Guo et al., 2015).

There are two modes in ISORROPIA II's calculation: the forward mode and the reverse mode. In the forward mode, the inputs include total concentrations (i.e., gas + particle) of $\mathrm{TNH}_{3}, \mathrm{TNO}_{3}, \mathrm{TCl}\left(\mathrm{HCl}+\mathrm{Cl}^{-}\right), \mathrm{SO}_{4}, \mathrm{NVCs}$, and meteorological parameters (temperature and $\mathrm{RH}$ ); in the reverse mode, only the particle phase of compounds and meteorological parameters are needed (Fountoukis and Nenes, 2007). In this study, the ISORROPIA II model is run in the forward mode for aerosols in a metastable state because the concentrations of both gas and particle species are available and also because the reverse mode has been reported to be more sensitive to measurement errors (Hennigan et al., 2015; Song et al., 2018).

We find that there are measurements with unrealistically high $\mathrm{Ca}^{2+}$ concentrations (such that $\mathrm{Ca}^{2+}$ is more than LWC $\times 0.002$, i.e., the solubility of $\mathrm{Ca}^{2+}$ in aerosol liquid water). This may be due to the measurement method of $\mathrm{Ca}^{2+}$ which uses large amounts of water to dissolve filter-collected particles. This process will likely dissolve the water-insoluble part of $\mathrm{Ca}^{2+}$ in aerosols which may cause higher bias in aerosol $\mathrm{Ca}^{2+}$ concentrations. In the existence of aerosol $\mathrm{SO}_{4}^{2-}, \mathrm{Ca}^{2+}$ precipitates along with $\mathrm{SO}_{4}^{2-}$ as
$\mathrm{CaSO}_{4}$ because of the low solubility (Seinfeld and Pandis, 2006). Including the high $\mathrm{Ca}^{2+}$ concentration leads to large differences in estimated $\mathrm{pH}$ because of the high acidity of $\mathrm{SO}_{4}^{2-}$ (Sect. S2). In order to avoid this potential bias, we use a modified $\mathrm{Ca}^{2+}$ concentration for $\mathrm{pH}$ calculations while keeping $\mathrm{SO}_{4}^{2-}$ unchanged. That is, we use the original $\mathrm{Ca}^{2+}$ concentration to calculate aerosol LWC and then use the concentration of $\mathrm{Ca}^{2+}$ that can dissolve in the LWC as the modified $\mathrm{Ca}^{2+}$ concentration in cases where the original $\mathrm{Ca}^{2+}$ exceeds its solubility in the calculated LWC.

We compare the directly measured gas-particle partitioning ratios of semi-volatile compounds with the ratios repartitioned by ISORROPIA II using measured total (gas + particle) concentrations as inputs. The purpose of this comparison, as conducted in previous studies (Guo et al., 2016, 2017a), is to examine the measurement data quality. This method is effective when the species have substantial fractions in both gas and particle phases (Guo et al., 2017a). The comparison results of $\varepsilon\left(\mathrm{NH}_{4}^{+}\right)$and $\varepsilon\left(\mathrm{NO}_{3}^{-}\right)$are shown in Fig. S3. The correlation coefficients and the slopes of linear regression are all close to 1 , suggesting good agreement between the measured and ISORROPIA-re-calculated partitioning ratios. In terms of these partitioning ratios, the model (ISORROPIA II) performs better in the USA than in China, which may be attributable, in part, to the more balanced partitioning of the species between gas and particle phases in the USA.

\subsection{Multivariable Taylor series method (MTSM)}

To separate the contribution of individual components (eight species in total, including $\mathrm{Na}^{+}, \mathrm{SO}_{4}, \mathrm{TNO}_{3}, \mathrm{TNH}_{3}, \mathrm{TCl}$, $\mathrm{Ca}^{2+}, \mathrm{K}^{+}$, and $\mathrm{Mg}^{2+}$ ) and meteorological variables $(\mathrm{RH}$ and temperature) to the $\mathrm{pH}$ difference between China and the USA, we propose a multivariable Taylor series method (MTSM). First, we derive the average conditions (i.e., species concentrations and meteorological conditions) across all the sites in the USA and China. We then use the USA as the starting point and China as the end point and decompose the contributions of individual compounds to the $\mathrm{pH}$ difference based on the following equations:

$$
\begin{aligned}
& \Delta c_{i}=c_{i, \text { China }}-c_{i, \text { US }}, \\
& c_{i, \lambda} \cong c_{i, \mathrm{US}}+\Delta c_{i} \cdot \lambda \text {, } \\
& \Delta \mathrm{pH}=p H_{\text {China }}-p H_{\mathrm{US}}=\int_{0}^{1}\left(\sum_{i=1}^{10} \frac{\partial \mathrm{pH}}{\partial c_{i, \lambda}} \cdot \Delta c_{i}\right) \cdot \mathrm{d} \lambda \\
& \cong \sum_{s=1}^{100}\left(\sum_{i=1}^{10} \frac{\partial \mathrm{pH}}{\partial c_{i, \frac{s}{100}}} \cdot \Delta c_{i}\right) \cdot 0.01, \\
& \Delta \mathrm{pH}_{i} \cong \sum_{s=1}^{100} \frac{\partial \mathrm{pH}}{\partial c_{i, \frac{s}{100}}} \cdot \Delta c_{i} \cdot 0.01 \text {, }
\end{aligned}
$$

where subscript $i$ denotes a specific species or meteorological variable; $c_{i, \text { China }}$ and $c_{i, \mathrm{US}}$ represent the values of $i$ in 


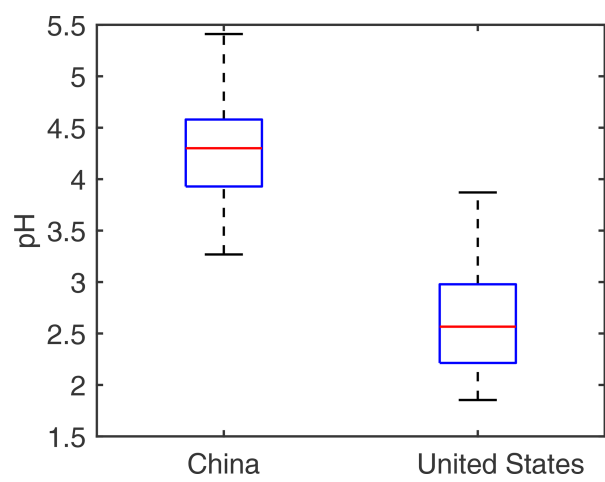

Figure 1. Annual average aerosol $\mathrm{pH}$ at each monitoring site in China and the United States based on observational data. The arithmetic mean (midline), the interquartile range (box), and the minimum-maximum range (whiskers) are shown in the box plot.

China and the USA, respectively; $\Delta c_{i}$ is the difference in $c_{i}$ between China and the USA; $c_{i, \lambda}$ is an intervening $c_{i}$ between $c_{i, \text { China }}$ and $c_{i, \text { US }}$ defined by $\lambda, \lambda \in[0,1]$; when $\lambda$ is 0 ,

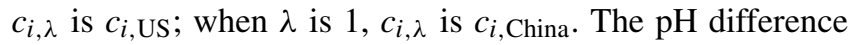
between China and the USA (i.e., $\Delta \mathrm{pH}$ ) can be expressed as the sum of the partial derivatives of $\mathrm{pH}$ with respect to $c_{i, \lambda}$ which is then integrated from $c_{i, \text { US }}$ to $c_{i, \text { China }}$, as described by Eq. (6). In this study, we take 100 steps with equal intervals to gradually change $\lambda$ from 0 to 1 (Eq. 6) and record the partial derivatives of $\mathrm{pH}$ with respect to individual $c_{i, \lambda}$ and derive the contributions of all the species and meteorological variables to the $\mathrm{pH}$ change at every step. By summing up the contributions of individual variables at all steps, we characterize the contributions of individual factors to the overall $\mathrm{pH}$ difference (Eq. 7). Based on the same method, we further quantify the contributions of individual factors to the differences in LWC and $\mathrm{H}_{\text {air }}^{+}$, respectively, the two variables directly used to calculate aerosol $\mathrm{pH}$ (Sect. 3).

\section{Results and discussion}

\subsection{The pH difference between China and the USA}

\subsubsection{The pH difference based on observations}

The sensitivity test to adjust the CASTNET-measured concentrations based on the reported average differences between weekly-duration and $24 \mathrm{~h}$ duration samples shows little difference between the unadjusted and adjusted $\mathrm{pH}$ values in the USA $(2.69 \pm 0.85$ and $2.74 \pm 0.83$ on average for the unadjusted and adjusted $\mathrm{pH}$, respectively), suggesting that the weekly duration of the CASTNET sampling has little impact on the calculated aerosol $\mathrm{pH}$. Therefore, we proceed with our subsequent analyses using the unadjusted $\mathrm{pH}$. The aerosol $\mathrm{pH}$ values calculated based on observational data show a significant difference between China (most observation sites are in the NCP) and the USA. In China (mainly the NCP), the 2017 annual average $\mathrm{pH}$ at monitoring sites is 4.3 , ranging from 3.3 to 5.4 with an interquartile range of 3.9-4.6. In the contiguous USA, the 2011 annual average $\mathrm{pH}$ is 2.6 , ranging from 1.9 to 3.9 with an interquartile range of 2.2-3.0 (Fig. 1). The $t$ test shows a statistically significant difference between the two groups $(p<0.0001)$, suggesting that the aerosols are on average more acidic at the monitoring sites in the contiguous USA than in China (NCP).

The $\mathrm{pH}$ difference is also illustrated by the cumulative distribution function (CDF) curves (Fig. 2, solid lines). The shapes of the CDF curves are similar in these two countries with a slightly steeper slope in the contiguous USA (Fig. 2a). The $\mathrm{pH}$ values, however, are 1-2 units higher in China (NCP) than in the contiguous USA across varying levels of cumulative frequencies in the CDF curves. In some cases, aerosols could be completely neutral in China (NCP) (the frequency is $2 \%$ for $\mathrm{pH} \geq 7$ ), while in the contiguous USA, the $\mathrm{pH}$ values in all cases were below 6 .

Spatially, 14 out of the 16 sampling sites in China are in the NCP (Fig. S2c) which is one of the most populous and polluted regions in China (Hu et al., 2014; Cui et al., 2020). Our $\mathrm{pH}$ results in this region are consistent with those of other studies (ranging from 3.5 to 4.6) (Liu et al., 2017; Ding et al., 2019; Ge et al., 2019). The distribution of sampling sites in the USA, on the other hand, is more evenly distributed spatially. The $\mathrm{pH}$ values in the midwest and California are higher than in other regions like the southeast, in line with previous studies (Lawal et al., 2018; Chen et al., 2019). Overall, the pH level in the USA is 1.7 units lower than over the NCP of China.

\subsubsection{The pH difference based on model simulations}

To address the issue of insufficient spatial coverage of the observational data in China, we conduct simulations using CMAQ, in conjunction with the observational data, to further study the $\mathrm{pH}$ difference on a nationwide scale. We evaluate the model performance by comparing the modeled and observed aerosol $\mathrm{pH}$ values (Fig. 3); major particle and gaseous species including $\mathrm{SO}_{4}^{2-}, \mathrm{NO}_{3}^{-}, \mathrm{NH}_{4}^{+}$and $\mathrm{HNO}_{3}$, and $\mathrm{NH}_{3}$; and the partitioning ratios including $\varepsilon\left(\mathrm{NH}_{4}^{+}\right)$and $\varepsilon\left(\mathrm{NO}_{3}^{-}\right)$, at monitoring sites (Figs. S4-S6).

Spatially, the model simulations generally capture the observed variations in $\mathrm{pH}$, species concentrations, and partitioning ratios, although there are some notable biases (Figs. S4 and S5). In both China (NCP) and the contiguous USA, the modeled $\mathrm{NH}_{4}^{+}, \mathrm{NO}_{3}^{-}$, and $\mathrm{NH}_{3}$ are biased low while modeled $\mathrm{HNO}_{3}$ is biased high, resulting in low biases in the predicted $\varepsilon\left(\mathrm{NO}_{3}^{-}\right)$and $\varepsilon\left(\mathrm{NH}_{4}^{+}\right)$. The modeled $\mathrm{SO}_{4}^{2-}$ in both countries is biased low. Such low biases have been seen in previous studies (Fountoukis et al., 2013; Theobald et al., 2016) and have been attributed to the spatial mismatch between the observations and simulations due to the coarse resolutions of model grid cells (usually $20-50 \mathrm{~km}$ resolution) (Shen et al., 2014; R. Wang et al., 2014). Smaller NMBs in 

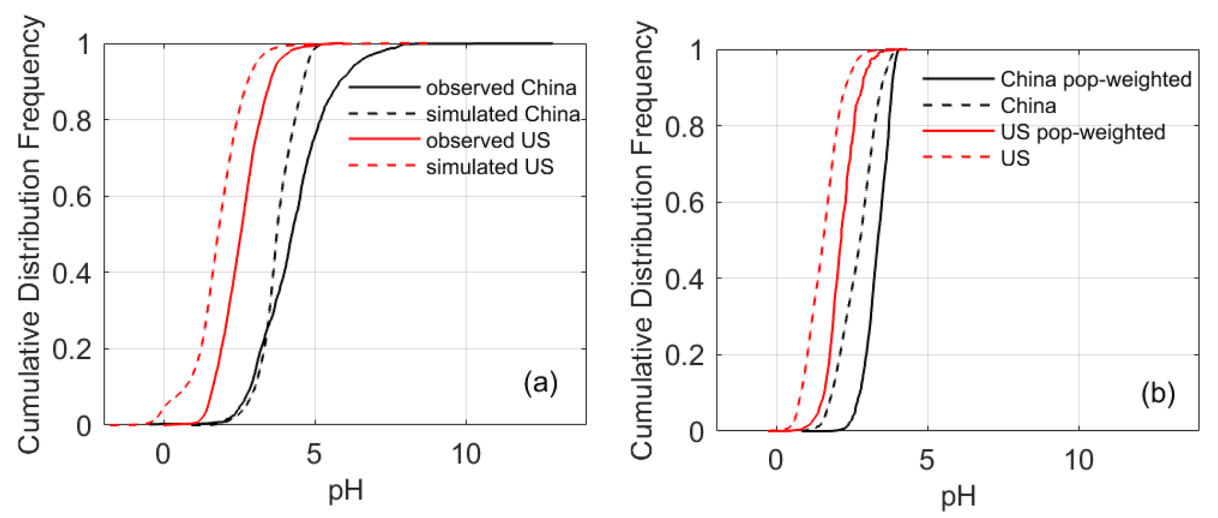

Figure 2. The cumulative distribution function (CDF) curves of aerosol pH in China and the United States based on (a) observed particulate and gaseous composition (solid lines) and CMAQ simulations collocated with observation sites (dashed line) and (b) simulated data nationwide. In panel (b), both average and population-weighted CDFs are shown.
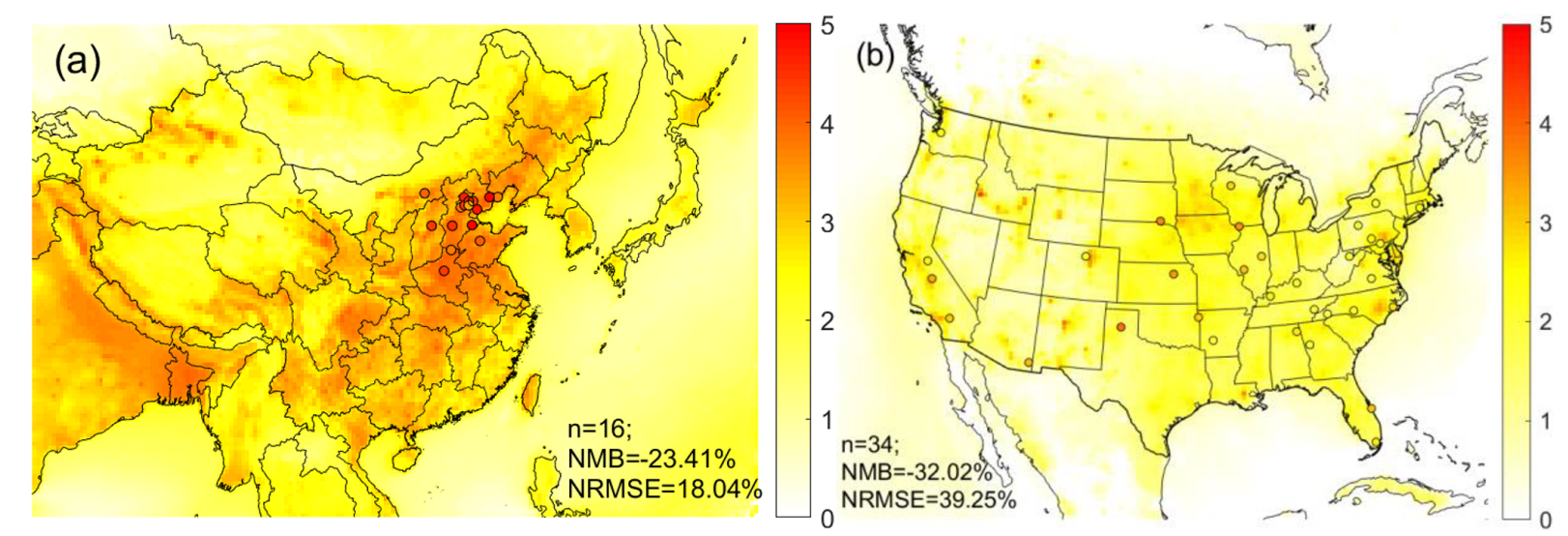

Figure 3. Overlay of annual mean $\mathrm{pH}$ calculated based on simulated concentrations (colored map) and observed concentrations (colored dots) over the study domain in (a) China and (b) the United States. Number of sites $(N)$, normalized mean bias (NMB), and normalized rootmean-square error (NRMSE) are provided in each figure. The world shapefiles were obtained from Esri (ArcGIS Hub, Countries WGS84, http://www.arcgis.com/home/item.html?id=30e5fe3149c34df1ba922e6f5bbf808f, last access: 21 June 2019).

the USA indicate a better performance compared to China (NCP). Larger differences between observations and simulations in China (NCP) could also be caused by larger measurement uncertainties as the data in China are collected from different monitoring stations operated by individual research institutions (Wang et al., 2019) and thus lack unified quality control compared with data in the USA, which come from national monitoring networks (United States Environmental Protection Agency, National Atmospheric Deposition Program). The co-occurrence of low biases in $\varepsilon\left(\mathrm{NO}_{3}^{-}\right)$, which causes lower bias in aerosol $\mathrm{pH}$, and low biases in $\varepsilon\left(\mathrm{NH}_{4}^{+}\right)$ and $\mathrm{SO}_{4}^{2-}$, which cause higher bias in aerosol $\mathrm{pH}$, likely offset each other, resulting in small biases in aerosol pH. Indeed, the simulated average $\mathrm{pH}$ values at observation sites $(3.8 \pm 0.2$ in the NCP, China, and $1.8 \pm 0.5$ in the contiguous USA) are generally in line with the observed averages $(4.3 \pm 0.5$ in the NCP, China, and $2.6 \pm 0.5$ in the contiguous USA) (Fig. 3), although the model shows a moderate low bias in both countries. The larger $\mathrm{pH}$ difference in the USA than in China is likely due to the low bias in $\mathrm{TNH}_{3}$ to which the sensitivity of $\mathrm{pH}$ is found to be more pronounced in the USA than in China (discussed in detail in Sect. S1).

With respect to the temporal variation, the model captures the seasonal trends of $\mathrm{pH}, \varepsilon\left(\mathrm{NH}_{4}^{+}\right)$, and $\varepsilon\left(\mathrm{NO}_{3}^{-}\right)$in both countries, with lower values in summer and higher values in winter (Fig. 4). The lower temperature in winter favors the partitioning toward the particle phase for semi-volatile species. Comparison of the seasonal trends of the individual aerosol components shows a better agreement in the USA than in China. For example, the simulation in the USA captures the trends of almost all components, though it is biased low for $\mathrm{SO}_{4}^{2-}$ and $\mathrm{NH}_{4}^{+}$in summer (Fig. S6b and h); the simulation in China misses the peaks of $\mathrm{SO}_{4}^{2-}$ in winter and $\mathrm{NH}_{3}$ in summer and has high biases for $\mathrm{HNO}_{3}$ in summer (Fig. S6a, i, and e). Measurement-related biases may contribute to the disparity in the temporal trends between 

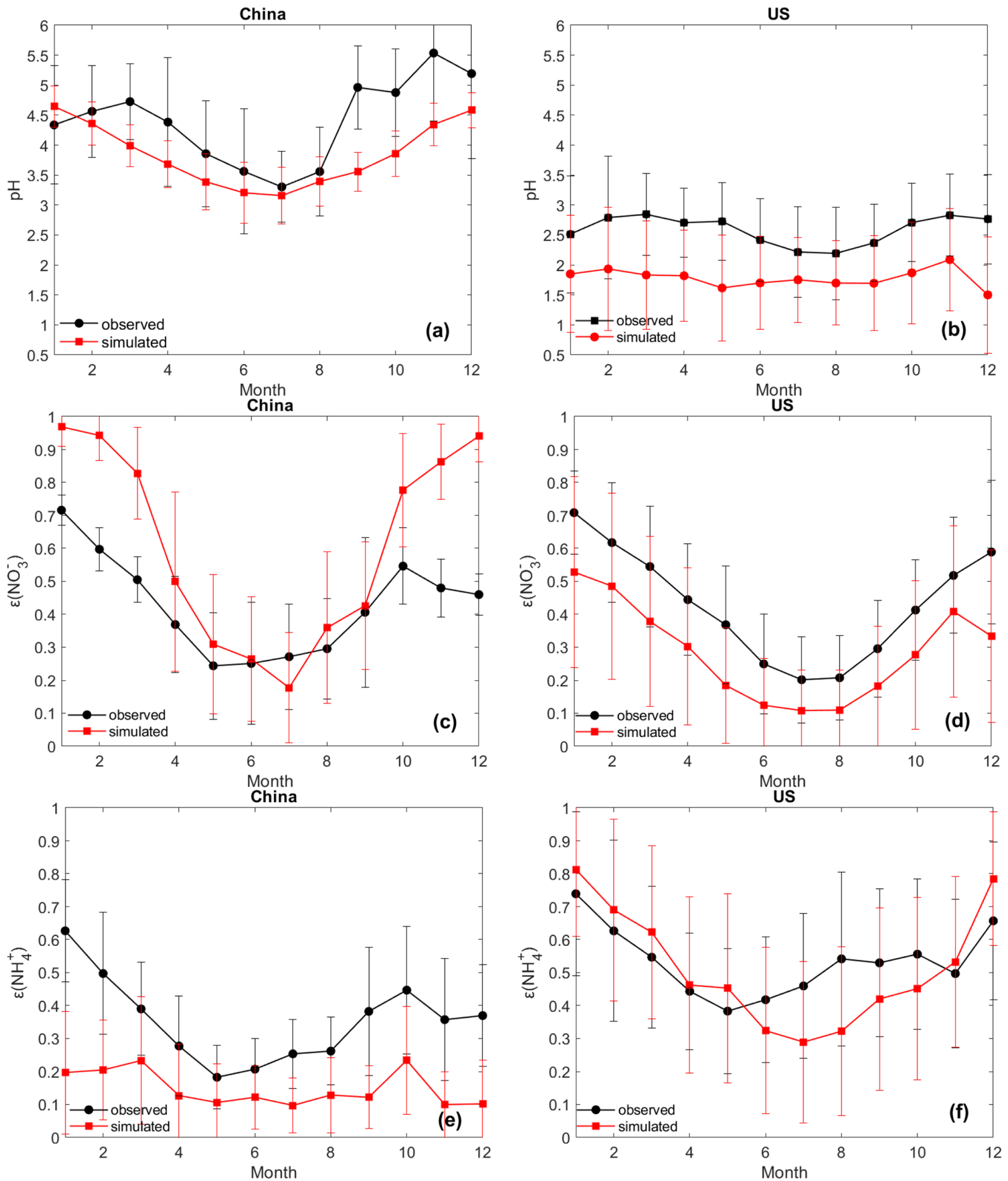

Figure 4. Monthly average values of $\mathrm{pH}, \varepsilon\left(\mathrm{NO}_{3}^{-}\right)$, and $\varepsilon\left(\mathrm{NH}_{4}^{+}\right)$based on observed and CMAQ-simulated data in China (a, $\mathbf{c}$, e) and in the United States $(\mathbf{b}, \mathbf{d}, \mathbf{f})$. The error bars represent the standard deviation of all the cases in each month. 
observed and modeled concentrations. The uncertainty in monthly profiles of emission estimates may also play an important role. For example, CASTNET's long sampling period could lead to a larger measurement bias in summer than in winter (Sickles and Shadwick, 2008); the large uncertainty in the current estimates of $\mathrm{NH}_{3}$ emissions in China, especially the reported underestimation of summertime emissions as indicated by an inversion analysis (Kong et al., 2019), may cause the absence of the summertime $\mathrm{NH}_{3}$ peak in the simulated trend (Fig. S6i). Further investigation is needed to better understand the factors underpinning the disparity between observations and model simulations. In spite of the various potential uncertainties, overall, the spatial and temporal evaluation suggests generally good agreement between the model simulations and observations in both countries.

In line with observations (Sect. 3.1.1), the nationwide model simulations show significant differences in aerosol acidity between the two countries. Almost all the areas in the USA have aerosol $\mathrm{pH}$ values lower than 3 according to the CDF (Fig. 2b). Higher pH values are found in the middle and eastern USA, while in the western USA except California, the $\mathrm{pH}$ values are lower (Fig. 3). In China, a large portion of areas ( $87 \%$ ) have aerosol $\mathrm{pH}$ values above 3 according to the CDF. This is especially true in eastern China which has the largest population (Fig. 3). Aerosol pH values in western and southeastern China are generally lower than in the east. It should be noted that due to the scarcity of observational data, the $\mathrm{pH}$ estimates in southern and western China are not evaluated. The nationwide annual average $\mathrm{pH}$ values in China and the USA are $2.7 \pm 0.6$ and $0.8 \pm 0.8$ units, respectively, lower than the observation-based values due partly to the model bias but also because most of the monitoring sites are in areas with high pH (Fig. 3).

Given the adverse health impacts of ambient aerosols (Burnett et al., 2014; Freedman et al., 2019) and the potential linkage of aerosol acidity with aerosol toxicity through the solubility of redox-active metals (Oakes et al., 2012; Fang et al., 2015; Ye et al., 2018), we further calculate and compare the population-weighted averages of aerosol $\mathrm{pH}$ in the two countries to highlight the $\mathrm{pH}$ levels in densely populated areas. The population-weighted $\mathrm{pH}$ values are $3.3 \pm 0.4$ and $2.2 \pm 0.5$ in China and the USA, respectively, both of which are higher than non-weighted averages, indicating that aerosols in more populous areas tend to be less acidic (Fig. 2b). This finding is further confirmed by the statistically significant positive correlation $(\alpha=0.01)$, within each country, between the aerosol $\mathrm{pH}$ and population density (for China, $r=0.42$ and $p<0.0001$; for the USA, $r=0.28$ and $p<0.0001)$. Consistent with the observation-based results, the $t$ test for the model simulations shows a significant difference in both the population-weighted and non-weighted aerosol $\mathrm{pH}$ values between the two countries $(p<0.001)$.
Table 1. Summary of the 1-year average values of mass concentration of water-soluble ions (WSI), gaseous and aerosol species, aerosol $\mathrm{pH}$ and meteorological parameters (as average \pm standard deviation) in China and the United States during the study periods (i.e., 2017 for China and 2011 for the United States).

\begin{tabular}{|c|c|c|}
\hline & China $(n=1845)$ & USA $(n=1191)$ \\
\hline WSI $\left(\mu \mathrm{g} \mathrm{m}^{-3}\right)$ & $34.4 \pm 25.5$ & $5.7 \pm 2.2$ \\
\hline Temperature (K) & $284.8 \pm 11.7$ & $287.4 \pm 10.0$ \\
\hline $\mathrm{RH}(\%)$ & $45.1 \pm 17.6$ & $71.4 \pm 20.9$ \\
\hline $\mathrm{pH}$ & $4.3 \pm 1.2$ & $2.6 \pm 0.7$ \\
\hline \multicolumn{3}{|c|}{ Particle phase $\left(\mu \mathrm{g} \mathrm{m}^{-3}\right)$} \\
\hline $\mathrm{SO}_{4}^{2-}$ & $9.2 \pm 7.1$ & $2.2 \pm 1.3$ \\
\hline $\mathrm{NO}_{3}^{-}$ & $12.1 \pm 11.1$ & $0.8 \pm 0.9$ \\
\hline $\mathrm{NH}_{4}^{+}$ & $8.9 \pm 8.0$ & $0.8 \pm 0.5$ \\
\hline $\mathrm{Cl}^{-}$ & $2.2 \pm 2.3$ & $0.4 \pm 0.1$ \\
\hline $\mathrm{Na}^{+}$ & $0.7 \pm 1.0$ & $0.2 \pm 0.2$ \\
\hline $\mathrm{K}^{+}$ & $0.7 \pm 0.6$ & $0.1 \pm 0.1$ \\
\hline $\mathrm{Ca}^{2+}$ & $1.0 \pm 0.1$ & $0.3 \pm 0.2$ \\
\hline $\mathrm{Mg}^{2+}$ & $0.2 \pm 0.1$ & $0.1 \pm 0.1$ \\
\hline \multicolumn{3}{|c|}{ Gaseous phase $\left(\mu \mathrm{g} \mathrm{m}^{-3}\right)$} \\
\hline $\mathrm{NH}_{3}$ & $18.0 \pm 12.6$ & $1.1 \pm 1.7$ \\
\hline $\mathrm{HCl}$ & $1.9 \pm 3.4$ & - \\
\hline $\mathrm{HNO}_{3}$ & $1.0 \pm 1.1$ & $1.0 \pm 0.6$ \\
\hline \multicolumn{3}{|l|}{ Total $\left(\mu \mathrm{g} \mathrm{m}^{-3}\right)$} \\
\hline $\mathrm{TNH}_{3}$ & $26.5 \pm 17.2$ & $1.9 \pm 1.8$ \\
\hline $\mathrm{TCl}$ & $4.1 \pm 4.5$ & - \\
\hline $\mathrm{TNO}_{3}$ & $13.1 \pm 11.2$ & $1.8 \pm 1.1$ \\
\hline
\end{tabular}

\subsection{Causes of the aerosol $\mathrm{pH}$ difference}

\subsubsection{Gaseous and particle compound profiles between China (NCP) and the contiguous USA}

We further investigate the factors leading to the $\mathrm{pH}$ difference. Although both observations and simulations are subject to uncertainty, we expect observations to provide more direct and reliable evidence for this investigation. It should be noted that the monitoring sites in China were clustered in the NCP and, thus, may not be representative of the whole of China. Table 1 summarizes the annual average concentrations of gaseous and particle species measured in China (NCP) and the contiguous USA during the study period (China, 2017; USA, 2011). For all the gaseous and ionic species (except $\mathrm{HNO}_{3}$ ), the average concentrations in China (NCP) are statistically significantly higher than those in the contiguous USA. The total concentrations of WSI species in China (NCP) $\left(34.4 \mu \mathrm{g} \mathrm{m}^{-3}\right)$ are on average 6 times the concentrations in the contiguous USA $\left(5.7 \mu \mathrm{g} \mathrm{m}^{-3}\right)$ and have greater variation, ranging from $0.2-240 \mu \mathrm{g} \mathrm{m}^{-3}$, compared to a range of $0.1-31 \mathrm{\mu g} \mathrm{m}^{-3}$ in the contiguous USA. Simi- 


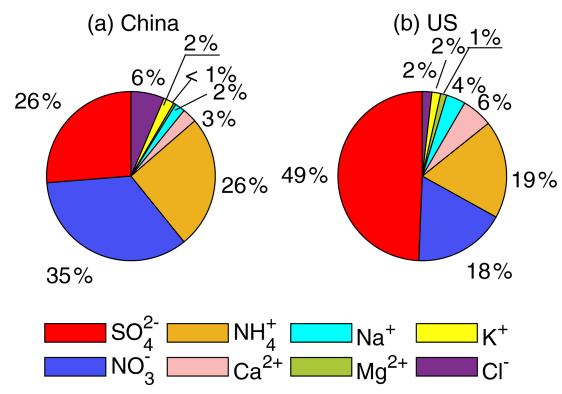

Figure 5. Annual average values of water-soluble ions (WSIs) concentration profiles in China (a) and in the United States (b).

larly to in other studies in China (Yao et al., 2002; Pathak et al., 2009; Zhang et al., 2013; Liu et al., 2016) and the USA (Guo et al., 2015; Feng et al., 2020), $\mathrm{NH}_{4}^{+}, \mathrm{NO}_{3}^{-}$, and $\mathrm{SO}_{4}^{2-}$, contribute more than $80 \%$ of the total WSI concentrations in both countries. The mass fractions of individual WSIs, however, differ between the two countries (Fig. 5). In China (NCP), the dominant WSI was $\mathrm{NO}_{3}^{-}(34.6 \%)$, followed by $\mathrm{SO}_{4}^{2-}(26.3 \%)$ and $\mathrm{NH}_{4}^{+}(25.5 \%)$. In the contiguous USA in $2011, \mathrm{SO}_{4}^{2-}$ contributed nearly half of the total WSI concentration $(49.4 \%)$, and the contributions of $\mathrm{NO}_{3}^{-}$and $\mathrm{NH}_{4}^{+}$ are comparable $\left(\mathrm{NO}_{3}^{-} 17.6 \%, \mathrm{NH}_{4}^{+} 18.8 \%\right)$. Note that $\mathrm{SO}_{4}^{2-}$ and $\mathrm{NO}_{3}^{-}$levels have been decreasing dramatically over the years, leading to decreases in $\mathrm{NH}_{4}^{+}$since there is less substrate to interact with $\mathrm{NH}_{3}$ and form particulate ammonium species (Butler et al., 2016).

Two of the most predominant anions in aerosols, $\mathrm{SO}_{4}^{2-}$ and $\mathrm{NO}_{3}^{-}$, at the monitoring sites in China (NCP) are present at 4 and 15 times the concentrations, respectively, of those observed in the contiguous USA. The relative difference in $\mathrm{NO}_{3}^{-}$between the two countries is the most significant, compared with the differences in other WSI components. Hence, the difference in the nitrate-to-sulfate molar ratio $\left(\mathrm{NO}_{3}^{-} / \mathrm{SO}_{4}^{2-}\right)$ is also significant between the two countries. The observational data show that the ratios at most monitoring sites in China (NCP) are larger than 1 and that only two sites have ratios lower than but close to $1(0.81,0.94)$. On the other hand, 27 out of the 34 sites in the contiguous USA show a ratio lower than 1, ranging from 0.250.99 . High $\mathrm{NO}_{3}^{-} / \mathrm{SO}_{4}^{2-}$ in China (NCP) could be caused by more efficient oxidation of $\mathrm{NO}_{x}$ than $\mathrm{SO}_{2}$ in China leading to greater nitrate formation as well as higher aerosol $\mathrm{pH}$ and availability of $\mathrm{NH}_{3}$ which favor the formation of particle nitrate (Guo et al., 2018b; Vasilakos et al., 2018). The varying ratios of $\mathrm{NO}_{3}^{-} / \mathrm{SO}_{4}^{2-}$ in aerosols could further affect aerosol liquid water uptake, which is discussed in the Supplement (Sect. S2).

The most abundant cation in aerosols is $\mathrm{NH}_{4}^{+}$, and the concentration difference in $\mathrm{NH}_{4}^{+}$between the two countries (by a factor of 11) is more significant than the difference in other cations (by factors of 2-7). In addition, $\varepsilon\left(\mathrm{NH}_{4}^{+}\right)$in
China (NCP) (0.13-0.48) is approximately $50 \%$ lower than in the contiguous USA $(0.22-0.85)$, meaning that compared to the USA, $\mathrm{TNH}_{3}$ in China tends to be present more in the gas phase. Higher $\mathrm{NH}_{4}^{+}$and lower $\varepsilon\left(\mathrm{NH}_{4}^{+}\right)$levels in China amount to a higher level of $\mathrm{TNH}_{3}$ which has an important influence on aerosol $\mathrm{pH}$, partitioning of $\mathrm{TNO}_{3}$, and even particulate mass (see Supplement for more discussion).

NVCs such as $\mathrm{Na}^{+}, \mathrm{Ca}^{2+}, \mathrm{Mg}^{2+}$, and $\mathrm{K}^{+}$are often minor components of particles but are important because of their ability to neutralize acidic species in the atmosphere, such as sulfuric and nitric acids (Zhang et al., 2007). Neglecting NVCs would cause low biases in $\mathrm{pH}$, driving the $\mathrm{NH}_{3}-\mathrm{NH}_{4}^{+}$equilibrium to shift toward the particle phase because more ammonium would be used to neutralize the aerosols that would otherwise be neutralized by NVCs (Guo et al., 2018a). Therefore, NVCs are included in calculating aerosol $\mathrm{pH}$ in this study. High NVC concentrations usually occur at the sites near emission sources. For example, high concentrations of $\mathrm{Na}^{+}$, mainly from sea salt (Zhang et al., 2011), occur at sites 13,27, and 30 in the USA, which are all coastal sites. High concentrations of $\mathrm{Ca}^{2+}$, mainly from mineral dust, are found at sites 6,11 , and 23 in the contiguous USA and at Site 5 in China (NCP), which are in prairies impacted by sand and dust. Average NVC concentrations in China (NCP) are up to an order of magnitude higher than in the contiguous USA, although in both countries, most of the NVCs concentrations are small compared to those of $\mathrm{SO}_{4}^{2-}$, $\mathrm{NO}_{3}^{-}$, and $\mathrm{NH}_{4}^{+}$. The predominant NVCs in China (NCP) are $\mathrm{Ca}^{2+}(2.8 \%), \mathrm{K}^{+}(2.1 \%)$, and $\mathrm{Na}^{+}(2.0 \%)$, and in the contiguous USA, they are $\mathrm{Ca}^{2+}(5.9 \%)$ and $\mathrm{Na}^{+}(3.7 \%)$.

\subsubsection{Characterization of contributions to aerosol acidity by individual factors}

We use the MTSM as described in Sect. 2.4 to characterize the contribution of each component to the $\mathrm{pH}$ difference between the USA and China. Three groups (i.e., observation, simulation non-weighted, simulation population-weighted) of the annual average concentrations in the USA and China listed in Table S4 are chosen as the starting (USA) and ending (China) points to perform the analysis. The results are shown in Fig. 6.

The average concentrations based on the observational and simulated data are not completely consistent due to the representativeness of the monitoring sites and the discrepancy between the simulations and observations. The MTSM analyses based on the three groups, however, show similar results. For example, all three groups suggest the high $\mathrm{TNH}_{3}$ in China as an important factor leading to the difference in aerosol $\mathrm{pH}$ between the two countries (Fig. 6). The contribution of $\mathrm{TNH}_{3}$ is the highest in the observation group due to the large difference in $\mathrm{TNH}_{3}$ concentration. Other cations, mainly NVCs, have a relatively small effect $(0.2,0.2$, and 0.3 in groups "observation", "simulation", and "simulationweighted", respectively), which is consistent with a previous 


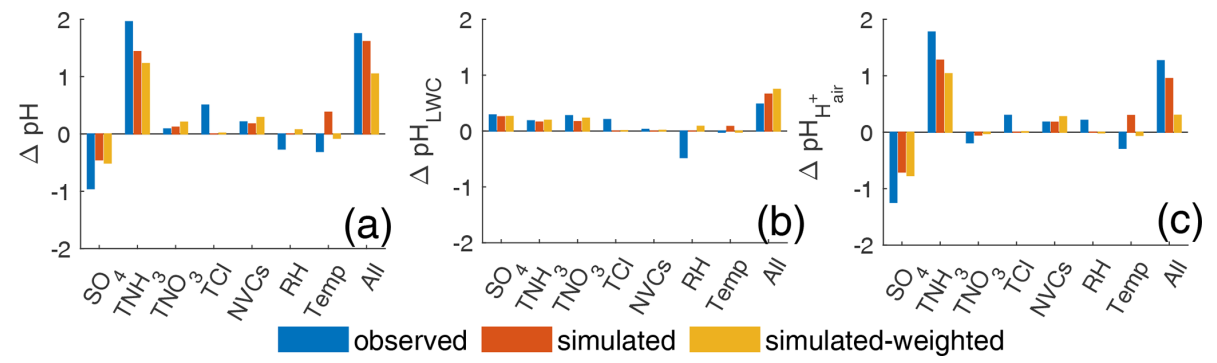

Figure 6. Contributions of individual components and meteorological factors to (a) total difference in aerosol $\mathrm{pH}(\Delta \mathrm{pH})$, (b) the aerosol $\mathrm{pH}$ difference through the pathway of $\mathrm{LWC}\left(\Delta \mathrm{pH}_{\mathrm{LWC}}\right)$, and (c) the aerosol $\mathrm{pH}$ difference through the pathway of $\mathrm{H}_{\text {air }}^{+}\left(\Delta \mathrm{pH}_{\mathrm{H}_{\text {air }}^{+}}\right)$between China and the United States calculated by the multivariable Taylor series method (MTSM) described in Sect. 2.4. For each factor, the sum of the contributions through the two pathways yields the net contribution of this factor to the aerosol $\mathrm{pH}$. The case in the United States is chosen as the starting point, and China is chosen as the ending point.

study (Zheng et al., 2020). Unlike $\mathrm{TNH}_{3}$ and NVCs which lead to higher $\mathrm{pH}$ values in China than in the USA, $\mathrm{SO}_{4}^{2-}$ contributes in the opposite direction to the $\mathrm{pH}$ difference. High $\mathrm{SO}_{4}^{2-}$ concentrations decrease aerosol $\mathrm{pH}$ in China by $0.6-1.3$ units, compared to the USA, although this effect is fully offset by $\mathrm{TNH}_{3}$.

Compared to other species, the concentrations of $\mathrm{TNO}_{3}$ are the most different between the two countries (by a factor of 15), but the MTSM shows that the contribution of $\mathrm{TNO}_{3}$ to the $\mathrm{pH}$ difference is relatively small $(0.1,0.1$, and 0.2 in the observation, non-weighted, and population-weighted groups). This result is further confirmed by a sensitivity test of $\mathrm{TNO}_{3}$ (Fig. S10) which shows that the change in $\mathrm{pH}$ from changing only $\mathrm{TNO}_{3}$ is small in both countries. More detailed analyses and discussions on the effects of $\mathrm{TNH}_{3}$, $\mathrm{TNO}_{3}$, and $\mathrm{SO}_{4}$ on aerosol $\mathrm{pH}$ can be found in the Supplement.

Studies have identified an important role of temperature in driving aerosol pH (Battaglia et al., 2017; Tao and Murphy, 2019; Jia et al., 2020). Our MTSM analysis shows that temperature accounts for 0.07-0.39 units of $\mathrm{pH}$ difference between China and the USA, which varies by group (Fig. 6). Such relatively small contributions of temperature, compared to those of $\mathrm{TNH}_{3}$ and $\mathrm{SO}_{4}$, are mainly because of the small difference in temperature between these two countries which are at similar latitudes. The difference in the annual average temperature between China and the USA is $1.4,-5.0$, and $2.6 \mathrm{~K}$ in the observation, non-weighted, and populationweighted groups, respectively (Table S4).

\subsubsection{Two pathways leading to the aerosol acidity difference}

As aerosol $\mathrm{pH}$ is calculated as $\left[\log _{10}(\mathrm{LWC})-\log _{10}\left(\mathrm{H}_{\text {air }}^{+}\right)-3\right]$, all mechanisms affecting aerosol $\mathrm{pH}$ must be through the modification of LWC, $\mathrm{H}_{\text {air }}^{+}$, or both (LWC and $\mathrm{H}_{\text {air }}^{+}$are expressed as mass per unit volume of air, $\mu \mathrm{g} \mathrm{m}^{-3}$ ). We quantitatively separate the contributions of individual factors to the China-US
$\mathrm{pH}$ difference into the LWC-modifying pathway and the $\mathrm{H}_{\text {air }}^{+}$-modifying pathway (Fig. 6). To achieve this, we use the MTSM to quantify the contributions of individual factors to the differences in $\log _{10}(\mathrm{LWC})$ and $\left[-\log _{10}\left(\mathrm{H}_{\text {air }}^{+}\right)-3\right]$ between the two countries, with the same approach as we did for $\mathrm{pH}$ (LWC and $\mathrm{H}_{\text {air }}^{+}$are two output variables directly predicted by ISORROPIA). The results show that the changes in both LWC and $\mathrm{H}_{\text {air }}^{+}$lead to increases in aerosol $\mathrm{pH}$ when conditions change from those in the USA to those in China.

Given that LWC increases with aerosol mass concentration (Song et al., 2019), higher component concentrations in China than in the USA increase LWC and, thus, increase aerosol pH (Fig. 6b). Through the LWC-modifying pathway, changes in $\mathrm{SO}_{4}, \mathrm{TNH}_{3}$, and $\mathrm{TNO}_{3}$ lead to increases in $\mathrm{pH}$ $(0.15-0.3)$ (Fig. 6b), which are consistent in all three groups. Compared to other groups, the observation group represents a higher $\mathrm{pH}$ increase due to $\mathrm{Cl}$ and a higher $\mathrm{pH}$ decrease due to RH (Fig. 6b), mainly because of the larger differences in $\mathrm{Cl}$ concentrations and $\mathrm{RH}$ for this group than for other groups (Table S4).

Through the $\mathrm{H}_{\text {air }}^{+}$-modifying pathway, the effects of individual factors on $\mathrm{pH}$ changes vary (Fig. 6c). Increases in acidic components $\left(\mathrm{SO}_{4}\right.$ and $\left.\mathrm{TNO}_{3}\right)$ increase $\mathrm{H}_{\text {air }}^{+}$and thus decrease aerosol pH (Fig. 6c). Increases in $\mathrm{TNH}_{3}, \mathrm{TCl}$, and NVCs, on the other hand, decrease $\mathrm{H}_{\text {air }}^{+}$and increase aerosol $\mathrm{pH}$ (Fig. 6c). By increasing $\mathrm{H}_{\text {air }}^{+}$, increased $\mathrm{SO}_{4}$ decreases $\mathrm{pH}$ by $0.7-1.2$ units, showing a much stronger acidic capacity than another acidic component, $\mathrm{TNO}_{3}$, which only decreases $\mathrm{pH}$ by $0.17-0.27$ units (Fig. 6c). Compared to the USA, China is in a $\mathrm{TNH}_{3}$-rich condition. The molar ratios of $\left[\mathrm{TNH}_{3}\right] /\left(2 \times\left[\mathrm{SO}_{4}\right]+\left[\mathrm{TNO}_{3}\right]+[\mathrm{TCl}]\right)$ in China vs. in the USA are 3 vs. $1.4,2.0$ vs. 1.0 , and 2.4 vs. 1.5 in the observation, non-weighted, and population-weighted groups, respectively. Changing the conditions from the USA to China, $\mathrm{TNH}_{3}$ plays the most important role in neutralizing the acidic components and driving the $\mathrm{pH}$ increase in the $\mathrm{H}_{\text {air }}^{+}$ modifying pathway (Fig. 6c). 
For individual factors, the net changes in $\mathrm{pH}$ are a result of the combination of the two pathways. For example, increased $\mathrm{SO}_{4}$ increases LWC and $\mathrm{H}_{\text {air }}^{+}$simultaneously. The increase in $\mathrm{LWC}$ increases aerosol $\mathrm{pH}$, while the increase in $\mathrm{H}_{\text {air }}^{+}$decreases aerosol $\mathrm{pH}$. All three groups suggest that the effect of $\mathrm{H}_{\text {air }}^{+}$on $\mathrm{pH}$ overwhelms that of $\mathrm{LWC}$ on $\mathrm{pH}$, leading to a net decrease in $\mathrm{pH}$ from an $\mathrm{SO}_{4}$ increase (Fig. 6). Increased $\mathrm{TNH}_{3}$ increases $\mathrm{pH}$ in both pathways, adding up to a larger increase in $\mathrm{pH}$ (Fig. 6). Increased $\mathrm{TNO}_{3}$ through these two pathways, however, is associated with opposite effects on $\mathrm{pH}$ which are comparable in magnitude and thus tend to offset each other (especially in the observation group) (Fig. 6). This explains the aforementioned small change in $\mathrm{pH}$ from the $\mathrm{TNO}_{3}$ increases. Combining all the factors, both pathways increase aerosol $\mathrm{pH}$ (Fig. $6 \mathrm{~b}$ and c), resulting in the large difference in aerosol acidity between these two countries (Fig. 6a).

To facilitate a follow-up sensitivity test to link the two pathways with mass concentration and chemical composition, we define the total mass concentration as the sum of the mass concentrations of all the eight input components (i.e., $\mathrm{Na}^{+}, \mathrm{SO}_{4}, \mathrm{TNH}_{3}, \mathrm{TNO}_{3}, \mathrm{TCl}, \mathrm{Ca}^{2+}, \mathrm{K}^{+}$, and $\mathrm{Mg}^{2+}$ ), including both gas and particle phases, and the chemical composition as the composition of the eight components in the aerosol (gas + particle) system. The observation group shows that the total mass concentration in China is 8.4 times that in the USA, and the chemical composition in China is richer in $\mathrm{TNH}_{3}$ than that in the USA (as illustrated by the ratios of $\left[\mathrm{TNH}_{3}\right] /\left(2 \times\left[\mathrm{SO}_{4}\right]+\left[\mathrm{TNO}_{3}\right]+[\mathrm{TCl}]\right)$ mentioned above). It has been found that both $\mathrm{LWC}$ and $\mathrm{H}_{\text {air }}^{+}$are affected by mass concentration and aerosol composition (Guo et al., 2015; Zheng et al., 2020; Xie et al., 2020). To investigate how the differences in mass concentration and composition between China and the USA are associated with the LWCand $\mathrm{H}_{\text {air }}^{+}$-modifying pathways and consequently the $\mathrm{pH}$ difference, we first increase the mass concentrations of individual input components in the US case by a constant factor of 8.4 , whereby we obtain an intervening case representing the overall pollution level as in China but with the chemical composition feature as in the USA (Table S4, sensitivity test). From the intervening case, we then shift the composition of the US case to that of China (Table S4, sensitivity test). Note that throughout this sensitivity test, meteorological conditions are held constant. The first step, by increasing the mass concentration, yields an increase of 1.02 units in the aerosol $\mathrm{pH}$, which is mainly achieved through the LWC-modifying pathway (1.06 units) instead of through the $\mathrm{H}_{\text {air }}^{+}$-modifying pathway ( -0.04 units) (Fig. S7a-c). The second step that changes the chemical composition shows a further increase of 0.76 units in the aerosol $\mathrm{pH}$, which is mainly achieved through the $\mathrm{H}_{\text {air }}^{+}$-modifying pathway (0.88 units). The LWCmodifying pathway plays a minor role $(-0.11$ units $)$ in this step (Fig. S7d-f). This sensitivity test reveals that the LWCmodifying pathway is mainly associated with the change in mass concentration and the $\mathrm{H}_{\text {air }}^{+}$-modifying pathway is mainly associated with the change in chemical composition.

It is surprising that in the first step, $\mathrm{pH}$ changed when the concentrations of all chemical components were scaled by a common factor. This means that $\mathrm{pH}$ changes with mass concentration of the aerosols (gas + particle) even though all chemical component mole fractions hold. Further investigation shows that increasing the aerosol concentration drives $\mathrm{TNO}_{3}$ and $\mathrm{TNH}_{3}$ partitioning toward particle phases $-\varepsilon\left(\mathrm{NH}_{4}^{+}\right)$and $\varepsilon\left(\mathrm{NO}_{3}^{-}\right)$increase from 0.4 and 0.6 to 0.6 and 0.98 , respectively. Given the weak acidity of $\mathrm{NO}_{3}^{-}$, the particle is ultimately neutralized by the increased $\mathrm{NH}_{4}^{+}$. The repartitioning in response to the increase in mass concentration is thus key to the $\mathrm{pH}$ shift and can be explained by Henry's law; i.e., $\left[A_{\mathrm{aq}}\right]=H_{A \cdot p_{A}}$, where $\left[A_{\mathrm{aq}}\right]$ is the aqueousphase concentration of component $A$ in units of moles per liter of water, $p_{A}$ is the partial pressure of $A$ in the gas phase, and $H_{A}$ is Henry's law coefficient (Seinfeld and Pandis, 2006). [ $\left.A_{\mathrm{aq}}\right]$ is proportional to $c_{A} / \mathrm{LWC}\left(c_{A}\right.$ denotes the particle-phase concentration of $A$; note that LWC and $c_{A}$ are expressed in mass per unit volume of air and $\left[A_{\mathrm{aq}}\right]$ is expressed in moles per unit volume of water). Increasing the concentrations of all chemical components by a common factor increases $p_{A}$ (due to the increase in the gas-phase concentration of $A$ ) but does not change [ $A_{\mathrm{aq}}$ ] (because both $c_{A}$ and LWC increases in the same direction by the same magnitude). According to Henry's law, more gas-phase $A$ will thus shift toward the particle phase to achieve a thermodynamic equilibrium of the new system.

We find that by increasing the concentration of every component by a constant factor, the magnitude and direction of the resulting change in $\mathrm{pH}$ are sensitive to the fraction of $\mathrm{TNH}_{3}$ in the aerosol system while insensitive to the ratio of $\mathrm{SO}_{4}$ to $\mathrm{TNO}_{3}$. Based on an $\mathrm{NH}_{4}^{+}-\mathrm{SO}_{4}^{2-}-\mathrm{NO}_{3}^{-}-\mathrm{H}_{2} \mathrm{O}$ system, we conduct a series of sensitivity tests to investigate the change in aerosol $\mathrm{pH}$ in response to the multiplication of a constant factor of 8.4 (Fig. S8). The change in $\mathrm{pH}$ reduces gradually from 1.2 units to 0.8 units when the $\mathrm{TNH}_{3}$ mass fraction of the system decreases from $67 \%$ to $27 \%$ (Fig. S8). With further decreases in the $\mathrm{TNH}_{3}$ fraction, the increase in $\mathrm{pH}$ diminishes rapidly, becomes negative when the $\mathrm{TNH}_{3}$ mass fraction is lower than $25 \%$, and is -0.6 when the $\mathrm{TNH}_{3}$ mass fraction is $17 \%$ (Fig. S8). Under a constant $\mathrm{TNH}_{3}$ mass fraction, the change in $\mathrm{pH}$ remains generally constant across a wide range of the mass ratios of $\mathrm{SO}_{4}$ to $\mathrm{TNO}_{3}$ (from $5: 1$ to $1: 5$ ) (Fig. S8). In populated continental regions, mass fractions of $\mathrm{TNH}_{3}$ are often high (Bencs et al., 2008; Behera and Sharma, 2010; Zheng et al., 2015; Cheng et al., 2016; Guo et al., 2017b), and an increase in mass concentration thus typically increases the aerosol $\mathrm{pH}$.

Such an assessment by tracking pathway- and step-specific contributions provides a better understanding of the $\mathrm{pH}$ difference between China and the USA. We show that through the LWC-modifying pathway, the increases in aerosol components consistently lead to increases in $\mathrm{pH}$ and that through 
the $\mathrm{H}_{\text {air }}^{+}$-modifying pathway, the effects of different components on $\mathrm{pH}$ vary in direction. If the LWC-modifying pathway dominated the $\mathrm{pH}$ changes over the $\mathrm{H}_{\text {air }}^{+}$-modifying pathway, aerosol mass concentrations would be the main factor driving the aerosol acidity difference between China and the USA and one could simply attribute the difference in aerosol acidity to the fact that China is more polluted than the USA. In contrast, if the $\mathrm{H}_{\text {air }}^{+}$-modifying pathway dominated, chemical composition would be the dominant factor and the compound profiles of precursors emissions, which affect the fractions of the corresponding aerosol components in the air, would play an important role. While there has been debate about whether mass concentration or chemical composition plays a more important role in determining aerosol pH (Cheng et al., 2016; Guo et al., 2017a; Pye et al., 2020; Zheng et al., 2020), our results suggest that both are important in explaining the China-US pH difference (Fig. 6b and c). The three groups are not consistent with each other in which pathway contributes more than the other to the $\mathrm{pH}$ difference, but they all suggest that the two pathways are comparable in terms of their effects on aerosol pH (Fig. $6 \mathrm{~b}$ and c).

Our results, showing the importance of both mass concentrations associated with LWC and chemical composition associated with $\mathrm{H}_{\text {air }}^{+}$and a minor role of temperature, seem in some aspects to contradict a previous study (Zheng et al., 2020) which highlighted LWC and temperature instead of chemical composition as the most important factors explaining the $\mathrm{pH}$ difference between China (NCP) and the USA. We note that the difference in the conclusions is reasonable when considering the differences in the specific cases examined in these two studies. The previous study compared the conditions in NCP in winter with those in the southeastern USA in summer (SE USA). Because of the differences in latitude (north for China vs. south for the USA) and season (winter for China vs. summer for the USA), the difference in temperature between their scenarios $(29 \mathrm{~K})$ was an order of magnitude greater than those in our study, which has greater spatial and temporal coverage $(2.6 \mathrm{~K}$ in the observation group, $5 \mathrm{~K}$ in the non-weighted group, and $-1.4 \mathrm{~K}$ in the population-weighted group). Using the MTSM, we evaluate the $\mathrm{pH}$ difference between the NCP and SE-USA scenarios considered in the previous study. The results show that temperature accounts for 1.3 units of difference in aerosol $\mathrm{pH}$ between their two scenarios (Fig. S9), in line with what was previously reported (1.6 units).

In addition, ISORROPIA simulations show a LWC difference of $8.2 \mu \mathrm{g} \mathrm{m}^{-3}$ between China (NCP) and the contiguous USA in the observation group in our study and $340 \mu \mathrm{g} \mathrm{m}^{-3}$ between the scenarios considered in the previous study. The much larger LWC difference in the previous study compared to ours is mainly driven by the differences in pollutant concentrations. For example, the $\mathrm{SO}_{4}$ concentration is as high as $156 \mu \mathrm{g} \mathrm{m}^{-3}$ in the NCP scenario in the previous study but only $9.2 \mu \mathrm{g} \mathrm{m}^{-3}$ in our study. Such differences in concentrations are reasonable, given that the previous study selected a severe haze event occurring in Beijing in winter 2013 as the scenario for China (NCP), while we use annual average levels over the NCP in 2017 as our case for China (NCP). Note that winter 2013 was a period when air pollution reportedly reached record high levels across northern China (Y. Wang et al., 2014; Li et al., 2016). Since 2013, China has launched strict controls on air pollutant emissions, and $\mathrm{PM}_{2.5}$ levels decreased significantly between 2013 and 2017 (Zhang et al., 2019). Therefore, the NCP scenario in the previous study should be more representative of short-term haze events in the pre-2013 period, while our China (NCP) case should be more representative of annual average levels in recent years.

\section{Conclusion and implications}

Based on extended ground-level measurements and regional air quality model simulations, we find significant differences in aerosol pH between China and the USA. Aerosols in the USA are on average more acidic with $\mathrm{pH}$ generally $1-2$ units lower than in China. We propose an MTSM to identify the key factors leading to the $\mathrm{pH}$ difference. The MTSM analysis reveals the important role of $\mathrm{TNH}_{3}$ in causing the $\mathrm{pH}$ difference and an opposing effect from $\mathrm{SO}_{4}$, which partially offsets the positive effect of $\mathrm{TNH}_{3}$ on the $\mathrm{pH}$ change. Other factors play relatively minor roles. Further investigation highlights two pathways related to the $\mathrm{pH}$ difference, one associated with changes in LWC and the other with changes in $\mathrm{H}_{\text {air }}^{+}$. The increased mass concentration in China, compared to the USA, enhances LWC, and the change in chemical composition toward a $\mathrm{TNH}_{3}$-rich condition reduces $\mathrm{H}_{\text {air }}^{+}$. Both pathways facilitate the increases in aerosol $\mathrm{pH}$ in China and are comparable in terms of driving the $\mathrm{pH}$ increase.

Previous studies have suggested that low aerosol $\mathrm{pH}$ is associated with increased toxicity because of the increased solubility of transition metals in aerosol LWC, which induce airway injury and inflammation through the production of reactive oxygen species in vivo (Kim et al., 2015). The lower aerosol $\mathrm{pH}$ in the USA than in China implies that aerosols in the USA may be more toxic than in China. However, this implication should be interpreted with caution because there are other known pathways through which particulate matter can harm humans and the mechanisms of how particulate matter affects health are not completely understood (Armstrong et al., 2004). More studies are needed to assess the health outcomes associated with the disparity in aerosol $\mathrm{pH}$ between the two countries.

Code availability. The CMAQv5.0.2 source code is available at https://doi.org/10.5281/zenodo.1079898 (United States Environmental Protection Agency, 2014). The ISORROPIA II source code is available at http://nenes.eas.gatech.edu/ISORROPIA/index_old. html (last access: 4 March 2021, Fountoukis and Nenes, 2007). 
Data availability. The data presented in this paper and the observational data in China can be obtained from the corresponding author upon request. The observational data in China can also be obtained from the data-sharing platform by the Comprehensive Observation Network for Air Pollution in Beijing-Tianjin-Hebei and Its Surrounding Areas (http://123.127.175.60:8765/siteui/index, last access: 18 November 2019, China National Environmental Monitoring Centre, 2019). The observational data in the USA can be obtained from the Clean Air Status and Trends Network (CASTNET) (https://www.epa.gov/castnet, last access: 23 January 2021, United States Environmental Protection Agency, 2021) and Ammonia Monitoring Network (AMoN) (http://nadp.slh.wisc.edu/amon/, last access: 23 January 2021, National Atmospheric Deposition Program, 2021).

Supplement. The supplement related to this article is available online at: https://doi.org/10.5194/acp-21-8341-2021-supplement.

Author contributions. HS initiated the research project. HS ran the model. HS and BZ designed the experiments, analyzed results, and wrote the initial draft of the manuscript. YH, SX, and ZX helped with data preparation. All co-authors commented on and contributed to the writing of the paper.

Competing interests. The authors declare that they have no conflict of interest.

Disclaimer. The contents of this paper are solely the responsibility of the grantee and do not necessarily represent the official views of the supporting agencies. Further, the US government does not endorse the purchase of any commercial products or services mentioned in the publication.

Financial support. This research has been supported by the US Environmental Protection Agency (grant no. R835880), the National Science Foundation (grant no. 1444745), and the National Air Pollution Prevention Joint Research Center of China (grant no. DQGG0204).

Review statement. This paper was edited by Armin Sorooshian and reviewed by two anonymous referees.

\section{References}

AiMa Air Quality Forecasting System: http://www.aimayubao.com/ wryb_eval.php?movie=no (last access: 4 January 2020), 2017.

Armstrong, B., Hutchinson, E., Unwin, J., and Fletcher, T.: Lung cancer risk after exposure to polycyclic aromatic hydrocarbons: a review and meta-analysis, Environ. Health Perspect., 112, 970978, https://doi.org/10.1289/ehp.6895, 2004.
Battaglia, M. A., Douglas, S., and Hennigan, C. J.: Effect of the Urban Heat Island on Aerosol pH, Environ. Sci. Technol., 51, 13095-13103, https://doi.org/10.1021/acs.est.7b02786, 2017.

Behera, S. N. and Sharma, M.: Investigating the potential role of ammonia in ion chemistry of fine particulate matter formation for an urban environment, Sci. Total Environ., 408, 3569-3575, https://doi.org/10.1016/j.scitotenv.2010.04.017, 2010.

Behera, S. N., Cheng, J., Huang, X., Zhu, Q., Liu, P., and Balasubramanian, R.: Chemical composition and acidity of sizefractionated inorganic aerosols of 2013-14 winter haze in Shanghai and associated health risk of toxic elements, Atmos. Environ., 122, 259-271, https://doi.org/10.1016/j.atmosenv.2015.09.053, 2015.

Bencs, L., Khaiwal, R., Hoog, J., Rasoazanany, E., Deutsch, F., Bleux, N., Berghmans, P., Roekens, E., Krata, A., and Van Grieken, R.: Mass and ionic composition of atmospheric fine particles over Belgium and their relation with gaseous air pollutants, J. Environ. Monitor., 10, 1148-1157, https://doi.org/10.1039/B805157G, 2008.

Burnett, R. T., Pope, C. A., 3rd, Ezzati, M., Olives, C., Lim, S. S., Mehta, S., Shin, H. H., Singh, G., Hubbell, B., Brauer, M., Anderson, H. R., Smith, K. R., Balmes, J. R., Bruce, N. G., Kan, H., Laden, F., Prüss-Ustün, A., Turner, M. C., Gapstur, S. M., Diver, W. R., and Cohen, A.: An integrated risk function for estimating the global burden of disease attributable to ambient fine particulate matter exposure, Environ. Health Perspect., 122, 397-403, https://doi.org/10.1289/ehp.1307049, 2014.

Butler, T., Vermeylen, F., Lehmann, C. M., Likens, G. E., and Puchalski, M.: Increasing ammonia concentration trends in large regions of the USA derived from the NADP/AMoN network, Atmos. Environ., 146, 132-140, https://doi.org/10.1016/j.atmosenv.2016.06.033, 2016.

Chen, Y. L., Shen, H. Z., and Russell, A. G.: Current and Future Responses of Aerosol $\mathrm{pH}$ and Composition in the US to Declining $\mathrm{SO}_{2}$ Emissions and Increasing NH3 Emissions, Environ. Sci. Technol., 53, 9646-9655, https://doi.org/10.1021/acs.est.9b02005, 2019.

Cheng, Y., Zheng, G., Wei, C., Mu, Q., Zheng, B., Wang, Z., Gao, M., Zhang, Q., He, K., Carmichael, G., Pöschl, U., and Su, H.: Reactive nitrogen chemistry in aerosol water as a source of sulfate during haze events in China, Sci. Adv., 2, e1601530, https://doi.org/10.1126/sciadv.1601530, 2016.

China National Environmental Monitoring Centre: Comprehensive Observation Network for Air Pollution in Beijing-Tianjin-Hebei and Its Surrounding Area, available at: http://123.127.175.60: 8765/siteui/index, last access: 18 November 2019.

Clegg, S. L., Brimblecombe, P., and Wexler, A. S.: Thermodynamic Model of the System $\mathrm{H}^{+}-\mathrm{NH}_{4}^{+}-\mathrm{SO}_{4}^{2-}-\mathrm{NO}_{3}^{-}-\mathrm{H}_{2} \mathrm{O}$ at Tropospheric Temperatures, J. Phys. Chem. A, 102, 2137-2154, https://doi.org/10.1021/jp973042r, 1998.

Cui, Y., Yin, Y., Chen, K., Zhang, X., Kuang, X., Jiang, H., Wang, H., Zhen, Z., and He, C.: Characteristics and sources of WSI in North China Plain: A simultaneous measurement at the summit and foot of Mount Tai, J. Environ. Sci., 92, 264-277, https://doi.org/10.1016/j.jes.2020.02.017, 2020.

Ding, J., Zhao, P., Su, J., Dong, Q., Du, X., and Zhang, Y.: Aerosol $\mathrm{pH}$ and its driving factors in Beijing, Atmos. Chem. Phys., 19, 7939-7954, https://doi.org/10.5194/acp-19-7939-2019, 2019. 
Fang, T., Guo, H., Verma, V., Peltier, R. E., and Weber, R. J.: $\mathrm{PM}_{2.5}$ water-soluble elements in the southeastern United States: automated analytical method development, spatiotemporal distributions, source apportionment, and implications for heath studies, Atmos. Chem. Phys., 15, 11667-11682, https://doi.org/10.5194/acp-15-11667-2015, 2015.

Fang, T., Guo, H., Zeng, L., Verma, V., Nenes, A., and Weber, R. J.: Highly Acidic Ambient Particles, Soluble Metals, and Oxidative Potential: A Link between Sulfate and Aerosol Toxicity, Environ. Sci. Technol., 51, 2611-2620, https://doi.org/10.1021/acs.est.6b06151, 2017.

Feng, J., Chan, E., and Vet, R.: Air quality in the eastern United States and Eastern Canada for 1990-2015: 25 years of change in response to emission reductions of $\mathrm{SO}_{2}$ and $\mathrm{NO}_{x}$ in the region, Atmos. Chem. Phys., 20, 3107-3134, https://doi.org/10.5194/acp-20-3107-2020, 2020.

Fountoukis, C. and Nenes, A.: ISORROPIA II: a computationally efficient thermodynamic equilibrium model for $\mathrm{K}^{+}-\mathrm{Ca}^{2+}$ $\mathrm{Mg}^{2+}-\mathrm{NH}^{4+}-\mathrm{Na}^{+}-\mathrm{SO}_{4}^{2-}-\mathrm{NO}_{3}^{-}-\mathrm{Cl}^{-}-\mathrm{H}_{2} \mathrm{O}$ aerosols, Atmos. Chem. Phys., 7, 4639-4659, https://doi.org/10.5194/acp-7-46392007, 2007.

Fountoukis, C., Koraj, D., Van Der Gon, H. D., Charalampidis, P., Pilinis, C., and Pandis, S.: Impact of grid resolution on the predicted fine PM by a regional 3-D chemical transport model, Atmos. Environ., 68, 24-32, 2013.

Freedman, M. A., Ott, E.-J. E., and Marak, K. E.: Role of $\mathrm{pH}$ in Aerosol Processes and Measurement Challenges, The J. Phys. Chem. A, 123, 1275-1284, https://doi.org/10.1021/acs.jpca.8b10676, 2019.

Ge, B., Xu, X., Ma, Z., Pan, X., Wang, Z., Lin, W., Ouyang, B., Xu, D., Lee, J., Zheng, M., Ji, D., Sun, Y., Dong, H., Squires, F. A., Fu, P., and Wang, Z.: Role of Ammonia on the Feedback Between AWC and Inorganic Aerosol Formation During Heavy Pollution in the North China Plain, Earth Space Sci., 6, 16751693, https://doi.org/10.1029/2019EA000799, 2019.

Guo, H., Xu, L., Bougiatioti, A., Cerully, K. M., Capps, S. L., Hite Jr., J. R., Carlton, A. G., Lee, S.-H., Bergin, M. H., Ng, N. L., Nenes, A., and Weber, R. J.: Fine-particle water and $\mathrm{pH}$ in the southeastern United States, Atmos. Chem. Phys., 15, 5211-5228, https://doi.org/10.5194/acp-15-5211-2015, 2015.

Guo, H., Sullivan, A. P., Campuzano-Jost, P., Schroder, J. C., LopezHilfiker, F. D., Dibb, J. E., Jimenez, J. L., Thornton, J. A., Brown, S. S., Nenes, A., and Weber, R. J.: Fine particle pH and the partitioning of nitric acid during winter in the northeastern United States, J. Geophys. Res.-Atmos., 121, 10355-10376, https://doi.org/10.1002/2016jd025311, 2016

Guo, H., Liu, J., Froyd, K. D., Roberts, J. M., Veres, P. R., Hayes, P. L., Jimenez, J. L., Nenes, A., and Weber, R. J.: Fine particle $\mathrm{pH}$ and gas-particle phase partitioning of inorganic species in Pasadena, California, during the 2010 CalNex campaign, Atmos. Chem. Phys., 17, 5703-5719, https://doi.org/10.5194/acp17-5703-2017, 2017a.

Guo, H., Weber, R. J., and Nenes, A.: High levels of ammonia do not raise fine particle $\mathrm{pH}$ sufficiently to yield nitrogen oxide-dominated sulfate production, Sci. Rep., 7, 12109, https://doi.org/10.1038/s41598-017-11704-0, 2017 b.

Guo, H., Nenes, A., and Weber, R. J.: The underappreciated role of nonvolatile cations in aerosol ammonium- sulfate molar ratios, Atmos. Chem. Phys., 18, 17307-17323, https://doi.org/10.5194/acp-18-17307-2018, 2018 a.

Guo, H., Otjes, R., Schlag, P., Kiendler-Scharr, A., Nenes, A., and Weber, R. J.: Effectiveness of ammonia reduction on control of fine particle nitrate, Atmos. Chem. Phys., 18, 12241-12256, https://doi.org/10.5194/acp-18-12241-2018, 2018b.

Gwynn, R. C., Burnett, R. T., and Thurston, G. D.: A time-series analysis of acidic particulate matter and daily mortality and morbidity in the Buffalo, New York, region, Environ. Health Perspect., 108, 125-133, https://doi.org/10.1289/ehp.00108125, 2000.

Hennigan, C. J., Izumi, J., Sullivan, A. P., Weber, R. J., and Nenes, A.: A critical evaluation of proxy methods used to estimate the acidity of atmospheric particles, Atmos. Chem. Phys., 15, 2775 2790, https://doi.org/10.5194/acp-15-2775-2015, 2015.

Hu, J., Wang, Y., Ying, Q., and Zhang, H.: Spatial and temporal variability of $\mathrm{PM}_{2.5}$ and $\mathrm{PM}_{10}$ over the North China Plain and the Yangtze River Delta, China, Atmos. Environ., 95, 598-609, https://doi.org/10.1016/j.atmosenv.2014.07.019, 2014.

Jang, M., Czoschke, N. M., Lee, S., and Kamens, R. M.: Heterogeneous Atmospheric Aerosol Production by AcidCatalyzed Particle-Phase Reactions, Science, 298, 814-817, https://doi.org/10.1126/science.1075798, 2002.

Jia, S., Chen, W., Zhang, Q., Krishnan, P., Mao, J., Zhong, B., Huang, M., Fan, Q., Zhang, J., Chang, M., Yang, L., and Wang, X.: A quantitative analysis of the driving factors affecting seasonal variation of aerosol $\mathrm{pH}$ in Guangzhou, China, Sci. Total Environ., 725, 138228, https://doi.org/10.1016/j.scitotenv.2020.138228, 2020.

Kim, K.-H., Kabir, E., and Kabir, S.: A review on the human health impact of airborne particulate matter, Environ. Int., 74, 136-143, https://doi.org/10.1016/j.envint.2014.10.005, 2015.

Kim, Y. P. and Seinfeld, J. H.: Atmospheric Gas-Aerosol Equilibrium: III. Thermodynamics of Crustal Elements $\mathrm{Ca}^{2+}, \mathrm{K}^{+}$, and $\mathrm{Mg}^{2+}$, Aerosol Sci. Technol., 22, 93-110, https://doi.org/10.1080/02786829408959730, 1995.

Kleinman, M. T., Phalen, R. F., Mautz, W. J., Mannix, R. C., McClure, T. R., and Crocker, T. T.: Health effects of acid aerosols formed by atmospheric mixtures, Environ. Health Perspect., 79, 137-145, https://doi.org/10.1289/ehp.8979137, 1989.

Kong, L., Tang, X., Zhu, J., Wang, Z., Pan, Y., Wu, H., Wu, L., Wu, Q., He, Y., Tian, S., Xie, Y., Liu, Z., Sui, W., Han, L., and Carmichael, G.: Improved Inversion of Monthly Ammonia Emissions in China Based on the Chinese Ammonia Monitoring Network and Ensemble Kalman Filter, Environ. Sci. Technol., 53, 12529-12538, https://doi.org/10.1021/acs.est.9b02701, 2019.

Lawal, A. S., Guan, X., Liu, C., Henneman, L. R. F., Vasilakos, P., Bhogineni, V., Weber, R. J., Nenes, A., and Russell, A. G.: Linked Response of Aerosol Acidity and Ammonia to $\mathrm{SO}_{2}$ and $\mathrm{NO}_{x}$ Emissions Reductions in the United States, Environ. Sci. Technol., 52, 9861-9873, https://doi.org/10.1021/acs.est.8b00711, 2018.

Li, J. and Jang, M.: Aerosol Acidity Measurement Using Colorimetry Coupled With a Reflectance UV-Visible Spectrometer, Aerosol Sci. Technol., 46, 833-842, https://doi.org/10.1080/02786826.2012.669873, 2012.

Li, S., Ma, Z., Xiong, X., Christiani, D. C., Wang, Z., and Liu, Y.: Satellite and Ground Observations of Severe Air Pollution Episodes in the Winter of 2013 in 
Beijing, China, Aerosol Air Qual. Res., 16, 977-989, https://doi.org/10.4209/aaqr.2015.01.0057, 2016.

Liu, M., Song, Y., Zhou, T., Xu, Z., Yan, C., Zheng, M., Wu, Z., $\mathrm{Hu}, \mathrm{M}$. , Wu, Y., and Zhu, T.: Fine particle $\mathrm{pH}$ during severe haze episodes in northern China, Geophys. Res. Lett., 44, 5213-5221, https://doi.org/10.1002/2017GL073210, 2017.

Liu, P., Zhang, C., Mu, Y., Liu, C., Xue, C., Ye, C., Liu, J., Zhang, Y., and Zhang, H.: The possible contribution of the periodic emissions from farmers' activities in the North China Plain to atmospheric water-soluble ions in Beijing, Atmos. Chem. Phys., 16, 10097-10109, https://doi.org/10.5194/acp-16-100972016, 2016.

Losey, D. J., Parker, R. G., and Freedman, M. A.: pH Dependence of Liquid-Liquid Phase Separation in Organic Aerosol, J. Phys. Chem. Lett., 7, 3861-3865, https://doi.org/10.1021/acs.jpclett.6b01621, 2016.

Losey, D. J., Ott, E.-J. E., and Freedman, M. A.: Effects of High Acidity on Phase Transitions of an Organic Aerosol, J. Phys. Chem. A, 122, 3819-3828, https://doi.org/10.1021/acs.jpca.8b00399, 2018.

Lyu, B., Zhang, Y., and Hu, Y.: Improving PM $_{2.5}$ Air Quality Model Forecasts in China Using a Bias-Correction Framework, Atmosphere, 8, 147, https://doi.org/10.3390/atmos8080147, 2017.

Mesinger, F., DiMego, G., Kalnay, E., Mitchell, K., Shafran, P. C., Ebisuzaki, W., Jović, D., Woollen, J., Rogers, E., Berbery, E. H., Ek, M. B., Fan, Y., Grumbine, R., Higgins, W., Li, H., Lin, Y., Manikin, G., Parrish, D., and Shi, W.: North American Regional Reanalysis, B. Am. Meteorol. Soc., 87, 343-360, https://doi.org/10.1175/bams-87-3-343, 2006.

Mo, Y., Li, J., Liu, J., Zhong, G., Cheng, Z., Tian, C., Chen, Y., and Zhang, G.: The influence of solvent and $\mathrm{pH}$ on determination of the light absorption properties of water-soluble brown carbon, Atmos. Environ., 161, 90-98, https://doi.org/10.1016/j.atmosenv.2017.04.037, 2017.

National Atmospheric Deposition Program: Ammonia Monitoring Network (AMoN), available at: http://nadp.slh.wisc.edu/AMoN/, last access: 23 January 2021.

National Atmospheric Deposition Program: Ammonia Monitoring Network (AMoN), available at: http://nadp.slh.wisc.edu/AMoN/, last access: 23 January 2021.

NCEP Product Inventory - Global Products: https://www.nco.ncep. noaa.gov/pmb/products/gfs/\#GFS, last access: 4 January 2020.

Nenes, A., Pandis, S. N., Weber, R. J., and Russell, A.: Aerosol $\mathrm{pH}$ and liquid water content determine when particulate matter is sensitive to ammonia and nitrate availability, Atmos. Chem. Phys., 20, 3249-3258, https://doi.org/10.5194/acp-203249-2020, 2020.

Oakes, M., Ingall, E. D., Lai, B., Shafer, M. M., Hays, M. D., Liu, Z. G., Russell, A. G., and Weber, R. J.: Iron Solubility Related to Particle Sulfur Content in Source Emission and Ambient Fine Particles, Environ. Sci. Technol., 46, 6637-6644, https://doi.org/10.1021/es300701c, 2012.

Pathak, R. K., Wu, W. S., and Wang, T.: Summertime $\mathrm{PM}_{2.5}$ ionic species in four major cities of China: nitrate formation in an ammonia-deficient atmosphere, Atmos. Chem. Phys., 9, 17111722, https://doi.org/10.5194/acp-9-1711-2009, 2009.

Pathak, R. K., Wang, T., Ho, K. F., and Lee, S. C.: Characteristics of summertime $\mathrm{PM}_{2.5}$ organic and elemental carbon in four major Chinese cities: Implications of high acidity for water- soluble organic carbon (WSOC), Atmos. Environ., 45, 318-325, https://doi.org/10.1016/j.atmosenv.2010.10.021, 2011.

Puchalski, M. A., Rogers, C. M., Baumgardner, R., Mishoe, K. P., Price, G., Smith, M. J., Watkins, N., and Lehmann, C. M.: A statistical comparison of active and passive ammonia measurements collected at Clean Air Status and Trends Network (CASTNET) sites, Environ. Sci.-Proc. Imp., 17, 358-369, https://doi.org/10.1039/C4EM00531G, 2015.

Pye, H. O. T., Nenes, A., Alexander, B., Ault, A. P., Barth, M. C., Clegg, S. L., Collett Jr., J. L., Fahey, K. M., Hennigan, C. J., Herrmann, H., Kanakidou, M., Kelly, J. T., Ku, I.-T., McNeill, V. F., Riemer, N., Schaefer, T., Shi, G., Tilgner, A., Walker, J. T., Wang, T., Weber, R., Xing, J., Zaveri, R. A., and Zuend, A.: The acidity of atmospheric particles and clouds, Atmos. Chem. Phys., 20, 4809-4888, https://doi.org/10.5194/acp-20-4809-2020, 2020.

Seinfeld, J. H. and Pandis, S. N.: Atmospheric chemistry and physics: from air pollution to climate change, John Wiley \& Sons, Inc., Hoboken, 1203 pp., 2006.

Shen, H. Z., Tao, S., Liu, J. F., Huang, Y., Chen, H., Li, W., Zhang, Y. Y., Chen, Y. C., Su, S., Lin, N., Xu, Y. Y., Li, B. G., Wang, X. L., and Liu, W. X.: Global lung cancer risk from PAH exposure highly depends on emission sources and individual susceptibility, Sci. Rep., 4, 6561, https://doi.org/10.1038/srep06561, 2014.

Shi, G., Xu, J., Peng, X., Xiao, Z., Chen, K., Tian, Y., Guan, X., Feng, Y., Yu, H., Nenes, A., and Russell, A. G.: pH of Aerosols in a Polluted Atmosphere: Source Contributions to Highly Acidic Aerosol, Environ. Sci. Technol., 51, 4289-4296, https://doi.org/10.1021/acs.est.6b05736, 2017.

Shi, X., Nenes, A., Xiao, Z., Song, S., Yu, H., Shi, G., Zhao, Q., Chen, K., Feng, Y., and Russell, A. G.: HighResolution Data Sets Unravel the Effects of Sources and Meteorological Conditions on Nitrate and Its GasParticle Partitioning, Environ. Sci. Technol., 53, 3048-3057, https://doi.org/10.1021/acs.est.8b06524, 2019.

Sickles, I. J. E., Hodson, L. L., and Vorburger, L. M.: Evaluation of the filter pack for long-duration sampling of ambient air, Atmos. Environ., 33, 2187-2202, https://doi.org/10.1016/S13522310(98)00425-7, 1999.

Sickles, J. E. and Shadwick, D. S.: Comparison of particulate sulfate and nitrate at collocated CASTNET and IMPROVE sites in the eastern US, Atmos. Environ., 42, 2062-2073, https://doi.org/10.1016/j.atmosenv.2007.11.051, 2008.

Skamarock, W. C., Klemp, J. B., Dudhia, J., Gill, D. O., Barker, D., Duda, M. G., Huang, X. Y., Wang, W., and Powers, J. G.: A description of the Advanced Research WRF version 3, NCAR Technical note-475+STR, 2008.

Song, S., Gao, M., Xu, W., Shao, J., Shi, G., Wang, S., Wang, Y., Sun, Y., and McElroy, M. B.: Fine-particle pH for Beijing winter haze as inferred from different thermodynamic equilibrium models, Atmos. Chem. Phys., 18, 7423-7438, https://doi.org/10.5194/acp-18-7423-2018, 2018.

Song, S., Nenes, A., Gao, M., Zhang, Y., Liu, P., Shao, J., Ye, D., Xu, W., Lei, L., Sun, Y., Liu, B., Wang, S., and McElroy, M. B.: Thermodynamic Modeling Suggests Declines in Water Uptake and Acidity of Inorganic Aerosols in Beijing Winter Haze Events during 2014/2015-2018/2019, Environ. Sci. Technol. Lett., 6, 752-760, https://doi.org/10.1021/acs.estlett.9b00621, 2019.

Surratt, J. D., Chan, A. W. H., Eddingsaas, N. C., Chan, M., Loza, C. L., Kwan, A. J., Hersey, S. P., Flagan, R. C., Wennberg, P. 
O., and Seinfeld, J. H.: Reactive intermediates revealed in secondary organic aerosol formation from isoprene, P. Natl. Acad. Sci. USA, 107, 6640, https://doi.org/10.1073/pnas.0911114107, 2010.

Tao, Y. and Murphy, J. G.: The sensitivity of $\mathrm{PM}_{2.5}$ acidity to meteorological parameters and chemical composition changes: 10-year records from six Canadian monitoring sites, Atmos. Chem. Phys., 19, 9309-9320, https://doi.org/10.5194/acp-199309-2019, 2019.

Theobald, M. R., Simpson, D., and Vieno, M.: Improving the spatial resolution of air-quality modelling at a European scale - development and evaluation of the Air Quality Regridder Model (AQR v1.1), Geosci. Model Dev., 9, 4475-4489, https://doi.org/10.5194/gmd-9-4475-2016, 2016.

United States Environmental Protection Agency: CASTNET Quality Assurance Quarterly Report, United States Environmental Protection Agency, 2012a.

United States Environmental Protection Agency: 2011 National Emissions Inventory (NEI) Data, available at: https://www.epa.gov/air-emissions-inventories/ 2011-national-emissions-inventory-nei-data (last access: 4 January 2020), 2012b.

United States Environmental Protection Agency: CMAQ (Version 5.0.2) [Software], Zenodo, https://doi.org/10.5281/zenodo.1079898, 2014.

United States Environmental Protection Agency: Clean Air Status and Trends Network (CASTNET), available at: https://www.epa. gov/castnet, last access: 23 January 2021.

Vasilakos, P., Russell, A., Weber, R., and Nenes, A.: Understanding nitrate formation in a world with less sulfate, Atmos. Chem. Phys., 18, 12765-12775, https://doi.org/10.5194/acp-18-127652018, 2018.

Wang, G., Zhang, R., Gomez, M. E., Yang, L., Levy Zamora, M., Hu, M., Lin, Y., Peng, J., Guo, S., Meng, J., Li, J., Cheng, C., Hu, T., Ren, Y., Wang, Y., Gao, J., Cao, J., An, Z., Zhou, W., Li, G., Wang, J., Tian, P., Marrero-Ortiz, W., Secrest, J., Du, Z., Zheng, J., Shang, D., Zeng, L., Shao, M., Wang, W., Huang, Y., Wang, Y., Zhu, Y., Li, Y., et al.: Persistent sulfate formation from London Fog to Chinese haze, P. Natl. Acad. Sci. USA, 113, 1363013635, https://doi.org/10.1073/pnas.1616540113, 2016.

Wang, R., Tao, S., Balkanski, Y., Ciais, P., Boucher, O., Liu, J., Piao, S., Shen, H., Vuolo, M. R., Valari, M., Chen, H., Chen, Y., Cozic, A., Huang, Y., Li, B., Li, W., Shen, G., Wang, B., and Zhang, Y.: Exposure to ambient black carbon derived from a unique inventory and high-resolution model, P. Natl. Acad. Sci. USA, 111, 2459-2463, https://doi.org/10.1073/pnas.1318763111, 2014.

Wang, S., Wang, L., Li, Y., Wang, C., Wang, W., Yin, S., and Zhang, R.: Effect of ammonia on fine-particle $\mathrm{pH}$ in agricultural regions of China: comparison between urban and rural sites, Atmos. Chem. Phys., 20, 2719-2734, https://doi.org/10.5194/acp20-2719-2020, 2020.

Wang, Y., Ying, Q., Hu, J., and Zhang, H.: Spatial and temporal variations of six criteria air pollutants in 31 provincial capital cities in China during 2013-2014, Environ. Int., 73, 413-422, https://doi.org/10.1016/j.envint.2014.08.016, 2014.

Wang, Y., Gong, Z., Liu, Z. L., Tang, G., Cheng, L., Che, F., Gao, J., and Ji, D.: Construction and Application of Comprehensive Observation Network for Air Pollution in Beijing-Tianjin-Hebei and Its Surrounding Areas, Environ. Sci. Res., 32, 1651-1663, https://doi.org/10.13198/j.issn.1001-6929.2019.09.12, 2019 (in Chinese).

Weber, R. J., Guo, H. Y., Russell, A. G., and Nenes, A.: High aerosol acidity despite declining atmospheric sulfate concentrations over the past 15 years, Nat. Geosci., 9, 282-285, https://doi.org/10.1038/Ngeo2665, 2016.

Xie, Y., Wang, G., Wang, X., Chen, J., Chen, Y., Tang, G., Wang, L., Ge, S., Xue, G., Wang, Y., and Gao, J.: Nitrate-dominated $\mathrm{PM}_{2.5}$ and elevation of particle $\mathrm{pH}$ observed in urban Beijing during the winter of 2017, Atmos. Chem. Phys., 20, 5019-5033, https://doi.org/10.5194/acp-20-5019-2020, 2020.

Yao, X., Chan, C. K., Fang, M., Cadle, S., Chan, T., Mulawa, P., He, K., and Ye, B.: The water-soluble ionic composition of $\mathrm{PM}_{2.5}$ in Shanghai and Beijing, China, Atmos. Environ., 36, 4223-4234, https://doi.org/10.1016/S1352-2310(02)00342-4, 2002.

Yarwood, G., Rao, S., Yocke, M., and Whitten, G. Z.: Updates to the carbon bond chemical mechanism: CB05, Final report to the U.S. EPA, RT-04-00675, available at: https://camx-wp.azurewebsites. net/Files/CB05_Final_Report_120805.pdf (last access: 26 May 2021), 2005.

Ye, D., Klein, M., Mulholland, J. A., Russell, A. G., Weber, R., Edgerton, E. S., Chang, H. H., Sarnat, J. A., Tolbert, P. E., and Ebelt Sarnat, S.: Estimating Acute Cardiovascular Effects of Ambient $\mathrm{PM}_{2.5}$ Metals, Environ. Health Perspect., 126, 027007, https://doi.org/10.1289/ehp2182, 2018.

Zhang, Q., Streets, D. G., He, K., and Klimont, Z.: Major components of China's anthropogenic primary particulate emissions, Environ. Res. Lett., 2, 045027, https://doi.org/10.1088/17489326/2/4/045027, 2007.

Zhang, Q., Zheng, Y., Tong, D., Shao, M., Wang, S., Zhang, Y., Xu, X., Wang, J., He, H., Liu, W., Ding, Y., Lei, Y., Li, J., Wang, Z., Zhang, X., Wang, Y., Cheng, J., Liu, Y., Shi, Q., Yan, L., Geng, G., Hong, C., Li, M., Liu, F., Zheng, B., Cao, J., Ding, A., Gao, J., Fu, Q., Huo, J., Liu, B., et al.: Drivers of improved $\mathrm{PM}_{2.5}$; air quality in China from 2013 to 2017, P. Natl. Acad. Sci. USA, 116, 24463, https://doi.org/10.1073/pnas.1907956116, 2019.

Zhang, R., Jing, J., Tao, J., Hsu, S.-C., Wang, G., Cao, J., Lee, C. S. L., Zhu, L., Chen, Z., Zhao, Y., and Shen, Z.: Chemical characterization and source apportionment of $\mathrm{PM}_{2.5}$ in Beijing: seasonal perspective, Atmos. Chem. Phys., 13, 7053-7074, https://doi.org/10.5194/acp-13-7053-2013, 2013.

Zhang, T., Cao, J., Tie, X., Shen, Z., Liu, S. X., Ding, H., Han, Y., Wang, G., Ho, K. F., Qiang, J., and Li, W. T.: Watersoluble ions in atmospheric aerosols measured in Xi' an, China: Seasonal variations and sources, Atmos. Res., 102, 110-119, https://doi.org/10.1016/j.atmosres.2011.06.014, 2011.

Zheng, G., Su, H., Wang, S., Andreae, M. O., Pöschl, U., and Cheng, Y.: Multiphase buffer theory explains contrasts in atmospheric aerosol acidity, Science, 369, 1374, https://doi.org/10.1126/science.aba3719, 2020.

Zheng, G. J., Duan, F. K., Su, H., Ma, Y. L., Cheng, Y., Zheng, B., Zhang, Q., Huang, T., Kimoto, T., Chang, D., Pöschl, U., Cheng, Y. F., and He, K. B.: Exploring the severe winter haze in Beijing: the impact of synoptic weather, regional transport and heterogeneous reactions, Atmos. Chem. Phys., 15, 2969-2983, https://doi.org/10.5194/acp-15-2969-2015, 2015. 